Ritrýnd grein birt 31. desember 2020

\title{
Nýliðun leikskólakennara, fjöldi brautskráðra og bakgrunnur leikskólakennaranema
}

\author{
Amalía Björnsdóttir og Puríður Jóna Jóhannsdóttir
}

Abstract

- Um höfunda

About the authors

Heimildir

Skortur á leikskólakennurum hefur verið viðvarandi á Íslandi en samkvæmt lögum eiga tveir priðju hlutar starfsmanna leikskóla að vera leikskólakennarar. Tilgangur pessarar rannsóknar er í fyrsta lagi að meta pörf fyrir nýliðun í stétt leikskólakennara miðað við stöðu og próun undanfarna áratugi. İ öðru lagi að skoða framvindu stúdenta í leikskólakennaranámi við Háskóla Íslands og draga upp mynd af bakgrunni peirra og aðstæðum. Frá 1998 til 2013 fjölgaði leikskólakennurum en eftir pað hefur peim fækkað og hlutfall eldri leikskólakennara í stéttinni er að aukast. Nýliðun hefur verið lítil par sem brautskráningum úr leikskólakennaranámi fækkaði eftir að krafist var fimm ára meistaranáms til starfsréttinda. Á sama tíma hefur leikskólabörnum fjölgað og viðverutími lengst. Af tölum um fjölda innritaðra og brautskráðra í leikskólakennaranámi við Háskóla Íslands á árunum 2015-2019 sést að innan við helmingur lýkur námi innan hefðbundinna tímamarka. Petta bendir til pess að um mikið brottfall geti verið að ræða og/eða að framvinda stúdenta í náminu sé hæg. Í niðurstöðum spurningakönnunar, sem lögð var fyrir leikskólakennaranema á fyrsta og öðru námsári, kemur fram að óhefðbundnir stúdentar eru í meirihluta, p.e. peir eru yfir 25 ára aldri pegar peir hefja nám, eru í sambúð og með börn á framfæri. Langflestir stunduðu námið í fjarnámi og unnu í leikskóla með námi og um helmingur í fullu starfi eða pví sem næst. Um tveir priðju hlutar leikskólakennaranemanna notuðu 20 klst. eða minna á viku í námið og pegar komið var á annað námsár höfðu $40 \%$ pátttakenda lokið sem samsvarar fullu námi á fyrsta námsári, sem bendir til að námstími til að ljúka fimm ára háskólanámi verði langur. Niðurstöðurnar benda til að vandinn skýrist af aðstæðum stúdenta sem gera pað að verkum að peir hafa ekki nægan tíma til að sinna náminu. Knýjandi er að finna leiðir til gera fleirum kleift að ljúka leikskólakennaranámi.

Efnisorð: Leikskólakennaranemar, leikskólakennaranám, óhefðbundnir háskólanemar, fjarnám, leikskólakennarar

\section{Inngangur}

Við Háskóla Îslands stunda nú ríflega 13 púsund stúdentar nám, hópur sem er með fjölbreyttan bakgrunn og býr við mismunandi aðstæður. Við skólann er ekki lengur hægt, fremur en í háskólum víða um heim, að ganga út frá pví að háskólanemar séu ungir, einhleypir og hafi nýlega lokið framhaldsskóla. Vaxandi hluti stúdenta tilheyrir hópi peirra sem gert hafa hlé á námi eftir að framhaldsskóla lauk og verið á vinnumarkaði í nokkur ár, og peir eru oft komnir með fjölskyldu með tilheyrandi skuldbindingum (sjá t.d. Chesters og Watson, 2016; Delaney, 2015; Masevičiūtė, Šaukeckienè og Ozolinčiūtė, 2018; Puríði Jóhannsdóttur og Amalíu Björnsdóttur, 2018, 2020). Talað er um pennan hóp sem óhefðbundna háskólanema (e. non-traditional students) og er pá oftast miðað við að peir séu 25 ára eða eldri pegar peir hefja háskólanám. Petta er fólk sem er almennt í launavinnu 
í hálfu og allt að fullu starfi og peir sem taka námið í fjarnámi vinna oft petta mikið með námi (Delaney, 2015). Háskólastúdentar sem eru yngri en 25 ára pegar peir hefja nám vinna flestir eitthvað með námi en yfirleitt í miklu lægra starfshlutfalli (Amalía Björnsdóttir, Puríður Jóhannsdóttir og Halla Jónsdóttir, 2019a, 2019b; Masevičiūtė o.fl., 2018). Peir sem hafa nýtt sér fjarnám á peim námsleiðum Háskóla Íslands par sem pað er í boði eru gjarnan í hópi óhefðbundinna háskólanema og pað á við um leikskólakennaranema. Rannsóknir hafa sýnt að nemum finnst helsti kostur fjarnáms að geta ráðið meiru um á hvaða tíma náminu er sinnt svo að unnt sé að stunda pað samhliða vinnu (Delaney, 2015). Fjarnemar eru almennt líklegri en staðnemar til að koma úr pjóðfélagsstéttum með stutta skólagöngu og hafa farið seint í háskólanám vegna aðstæðna sem tengjast stéttarstöðu (Delaney og Farren, 2016). Skuldbindingar vegna fjölskyldu og vinnu geta haft áhrif á námsframvindu pessara háskólanema, seinkað peim í námi eða aukið líkur á brottfalli (Delaney, 2015).

Skortur á leikskólakennurum hefur verið viðvarandi lengi og mönnun í íslenskum leikskólum er langt frá pví að vera í samræmi við lög sem gera ráð fyrir að tveir priðju hlutar starfsmanna séu leikskólakennarar en er í reynd um priðjungur (Ríkisendurskoðun, 2017). Fyrir um aldarfjórðungi var leikskólakennaranám fyrst skilgreint sem háskólanám á Íslandi en með lögum árið 2008 var krafist meistaraprófs til að öðlast starfsréttindi leikskólakennara (lög um menntun og ráðningu kennara og skólastjórnenda við leikskóla, grunnskóla og framhaldsskóla nr. 87/2008). Eftir lengingu námsins dró mjög úr fjölda brautskráđra leikskólakennara, og er hæg endurnýjun stéttarinnar pví áhyggjuefni. Mikilvægt er að draga upp skýra mynd af peim hópi sem stundar nám í leikskólakennarafræðum svo unnt sé að átta sig á aðstæðum nemanna og koma til móts við parfir peirra við skipulag námsins pannig að sem flestir sem innritast ljúki prófgráðu. Takist ekki að fjölga útskrifuðum leikskólakennurum má búast við að erfitt geti reynst að halda uppi faglegu uppeldis- og menntunarstarfi á pessu mikilvæga fyrsta skólastigi menntakerfisins á Íslandi.

Tilgangur pessar rannsóknar er að meta pörf fyrir nýliðun í stétt leikskólakennara út frá opinberum gögnum frá Hagstofu Íslands. Í öðru lagi að draga upp mynd af leikskólakennaranemum við Háskóla İslands, bakgrunni peirra og aðstæðum og gera grein fyrir fjölda innritaðra og brautskráðra, bæði á bakkalár- og meistarastigi.

\section{Baksvið}

\section{Upphaf leikskóla sem uppeldisstofnunar fyrir börn undir skólaaldri}

Með iðnvæðingu og aukinni péttbýlismyndun á Vesturlöndum jókst pörf fyrir sérstakar uppeldisstofnanir fyrir börn undir skólaaldri. Mikilvægi pess að bæta uppeldisskilyrði barna í borgum og pörf fyrir barnaheimili, einkum fyrir mæður sem voru fyrirvinnur heimilis síns, ýtti undir pessa próun. Pegar á 18. öld urðu til uppeldisstofnanir fyrir ung börn í Evrópu og í vaxandi mæli á 19. öld. Á Norðurlöndum var ötullega unnið að pví að koma barnaheimilum á fót í upphafi 20. aldar (Jón Torfi Jónasson, 2006).

Örar pjóðfélagsbreytingar með flutningum fólks úr sveit í péttbýli kölluðu hér eins og erlendis á úrræði til að bæta uppeldisskilyrði barna. Barnavinafélagið Sumargjöf var stofnað árið 1924 með pað meginmarkmið að reka barnaheimili og fyrsta heimili félagsins var stofnað í Reykjavík árið 1931, fyrstu árin eingöngu rekið á sumrin (Gils Guðmundsson, 1949; Valborg Sigurðardóttir, 1998). Á tímum seinni heimsstyrjaldarinnar fjölgaði konum á vinnumarkaði og eftir stríðið fjölgaði einstæðum mæðrum og eftirspurn eftir barnaheimilisplássum varð mikil. Á árunum 1945-1946 voru prjú heilsársbarnaheimili í Reykjavík par sem 230 börn gátu dvalið. Barnaheimili voru einnig rekin í nokkrum stærri bæjum par sem félög um barnavernd eða kvenfélög börðust fyrir pví að koma peim á fót og sáu einnig oft um reksturinn, stundum í samráði við bæjarfélögin sem lögðu fé til starfseminnar (Jón Torfi Jónasson, 2006). Eftir 1970 tók barnaheimilum að fjölga um allt land og báru ríkið og sveitarfélögin sameiginlega ábyrgð á kostnaði og rekstri par til 1989 að rekstur peirra færðist alfarið til sveitarfélaganna. Á pessum tíma var gerður greinarmunur á leikskólum par sem börn frá tveggja ára aldri gátu dvalið hálfan daginn, sem pótti góð viðbót við uppeldi á heimilum, 
og dagheimilum sem voru fyrir pá foreldra sem höfðu af einhverjum ástæðum pörf fyrir vistun fyrir börn sín allan daginn, svo sem einstæðar mæður og háskólastúdenta. Með lögum um leikskóla nr. 48/1991 var fallið frá pessari tvískiptingu og hugtakið leikskóli notað eingöngu. Í lögum um leikskóla nr. 78/1994 var tekið upp starfsheitið leikskólakennari og „tekur starfsheitið til peirra sem hafa lokið viðurkenndu fóstrunámi“, en pað er ekki fyrr en 2008 að starfsheitið varð lögverndað (lög um menntun og ráðningu kennara og skólastjórnenda við leikskóla, grunnskóla og framhaldsskóla nr. 87/2008).

Með lögunum frá 1991 er sú skylda lögð á sveitarfélög að stofna leikskóla en ríkisvaldið skal sinna eftirliti og bera faglega ábyrgð á starfinu. Í lögum nr. 78/1994 er leikskólinn formlega skilgreindur sem fyrsta skólastigið ætlað börnum undir skólaskyldualdri og fyrsta Aðalnámskrá leikskóla sem birtir stefnu stjórnvalda um faglega starfsemi leikskóla kom út árið 1999 (Menntamálaráðuneytið, 1999) en áđur höfðu verið gefnar út uppeldisáætlanir fyrir dagvistarheimili (Menntamálaráðuneytið, 1985) og leikskóla (Menntamálaráðuneytið, 1993).

Á Norðurlöndum eru leikskólar yfirleitt sama stofnunin fyrir öll börn undir skólaskyldualdri en víða í Evrópu er aldursskipting par sem yngri og eldri börn eru í aðskildum skólum. Alls staðar á Norðurlöndum nema Íslandi eiga börn lögum samkvæmt rétt á leikskólaplássi pegar fæðingarorlofi lýkur. Á Íslandi eru slík ákvæði ekki í lögum en flest sveitarfélög bjóða leikskólapláss frá tveggja ára aldri og í auknum mæli býðst yngri börnum leikskólavist. Í Evrópu voru að meðaltali 34\% barna undir priggja ára aldri í leikskóla árið 2017, rúm 70\% í Danmörku, tæp 65\% á Íslandi, rúm 50\% í Svípjóð og priðjungur í Finnlandi. Næstum helmingur Evrópuríkja tryggir börnum leikskólavist frá priggja ára aldri og alls staðar á Norðurlöndum er meirihluti priggja ára barna í leikskóla. Nánast öll fimm ára börn á Norðurlöndum eru í leikskóla, lægst hlutfall í Finnlandi, 85\%. Í flestum Evrópuríkjum hefst skyldunám barna við sex ára aldur (European Commission/EACEA/Eurydice, 2019).

\section{Uppvhaf og próun leikskólakennaranáms á Íslandi}

Á Norðurlöndum voru fyrstu skólar fyrir leikskólakennara stofnaðir upp úr aldamótunum 1900, yfirleitt tveggja ára nám (Valborg Sigurðardóttir, 1998). Árið 1946 voru aðeins prjár fóstrur við störf hjá Sumargjöf, sem starfrækti barnaheimili í Reykjavík, og „vöntun á hæfum starfsstúlkum“ hamlaði uppbyggingu barnaheimila (Tilvitnun í viðtal við Pórhildi Ólafsdóttur í Barnadagsblaðinu, 1946, í Valborg Sigurðardóttir, 1998, bls. 48). Uppeldisskóli, síðar Fóstruskóli Sumargjafar var stofnaður árið 1946 til að mennta forstöðukonur og fóstrur. Fyrstu árin voru teknar inn 10 stúlkur á ári og var tveggja ára námstímanum skipt jafnt á milli bóklegs og verklegs hluta. Skólinn var í húsnæðishraki og gat ekki tekið inn eins marga nema og pörf var á, pó einungis væri reiknað með menntuðum fóstrum í starf forstöðukvenna og deildarstjóra (Valborg Sigurðardóttir, 1998).

Árið 1968 var nám við Fóstruskólann lengt í prjú ár og fékk skólinn stöðu sérskóla á framhaldsskólastigi 1973 (lög um Fósturskóla Íslands nr. 10/1973). Stúdentspróf var inntökuskilyrði eða gagnfræðapróf að viðbættu tveggja ára námi og er litið á petta sem fyrstu skrefin í átt að pví að færa menntunina á háskólastig. Stefnt var að pví að flytja skólann á háskólastig og pegar Háskólinn á Akureyri stofnaði námsbraut í leikskólakennslu árið 1996 ýtti pað á að Fósturskólinn flyttist á háskólastig. Árið 1998 sameinuðust Fósturskóli Íslands, Proskapjálfaskóli Íslands, Ípróttakennaraskóli Îslands og Kennaraháskóli Íslands undir nafninu Kennaraháskóli Íslands. Par með varð leikskólakennaramenntun priggja ára háskólanám sem lauk með B.Ed.-gráðu. Með lögum nr. 87/2008 var gerð krafa um meistarapróf til að öðlast starfsréttindi leikskólakennari og brautskráðust síðustu nemar með starfsleyfi að loknu B.Ed.-námi árið 2011. Inntökuskilyrði í meistaranám var B.Ed.-gráða í leikskólakennarafræðum eða bakkalárgráða í öðru grunnnámi sem tengdist námssviðum leikskólans. Árið 2019 var lögum um menntun kennara breytt á pann hátt að 30 eininga meistaraverkefni parf ekki lengur að vera hluti af meistaraprófinu heldur er hægt að ljúka 120 eininga meistaranámi með námskeiðum eingöngu. Einnig er ákvæði ílögunum um eitt leyfisbréf fyrir kennara pvert á skólastig (lög um menntun, hæfni og ráðningu kennara og skólastjórnenda við leikskóla, grunnskóla og framhaldsskóla nr. 95/2019). 
Skortur á faglærðu starfsfólki í leikskólum hefur verið áhyggjuefni lengi og ýmislegt verið gert á síðustu árum til að stuðla að fjölgun leikskólakennara. Árið 2014 var hleypt af stokkunum átaki undir yfirskriftinni Framtíðarstarfið með pað að markmiði að efla ímynd leikskólans og fjölga peim sem hefja nám í leikskólakennarafræðum. Petta var samstarfsverkefni margra hagaðila (Stjórnarráðið, 2017). Verkefnið pótti bera góðan árangur par sem fjöldatölur háskólanna sýndu að aðsókn í námið jókst (Háskóli Íslands, 2017) og talað var um verulega fjölgun árið 2016 (Jóhanna Einarsdóttir, 2017). Sveitarfélög hafa einnig styrkt starfsmenn leikskóla til náms í leikskólakennarafræðum (Anna Lilja Pórisdóttir, 2015) og Félag leikskólakennara hefur veitt styrki til félagsmanna með bakkalárpróf til að sækja meistaranám sem veitir starfsréttindi leikskólakennara (Félag leikskólakennara, 2017).

\section{Menntun leikskólakennara og kröfur um menntun í Evrópu og á Norðurlöndum}

Í sampykktum Evrópuráðsins um félagsleg réttindi er ákvæði um aðöll börn eigi rétt á forskólamenntun par sem gæði eru tryggð. Árið 2019 kom út skýrsla með lykilupplýsingum um uppeldi og menntun ungra barna á forskólaaldri í Evrópu (European Commission/EACEA/Eurydice, 2019). Vỉða eru kröfur til menntunar starfsfólks ólíkar eftir aldri barna og meiri kröfur gerðar til peirra sem vinna með eldri börnin. Í um priðjungi Evrópuríkja er kveðið á um að lágmarksmenntun leikskólakennara sem leiða starf yngri barna sé bakkalárpróf en aðeins á Íslandi og í Portúgal er krafist meistaraprófs. Í meirihluta ríkja Evrópu (um 75\%) er gerð krafa um bakkalárpróf fyrir leikskólakennara eldri barna og í fjórum löndum; í Frakklandi, á Italíu, í Portúgal og á Îslandi, er krafan meistarapróf. Víðast hvar er ekki krafist sérstakrar menntunar fyrir annað starfsfólk en leikskólakennara en oft gerð krafa um almenna framhaldsskólamenntun og í sumum löndum framhaldsskólapróf af uppeldisbrautum. Pað á t.d. við um Finnland, par sem aðstoðarfólk í leikskóla parf að hafa lokið priggja ára námi á uppeldisbraut í framhaldsskóla.

Í Finnlandi og í Noregi er leikskólakennaranám priggja ára nám til bakkalárgráðu (Eurydice, e.d.) en priggja og hálfs árs nám í Danmörku og Svíbjóð. Î Svíbjóð er hægt að taka fjögurra ára nám sem veitir kennsluréttindi í leikskólum og 1.า-3. bekk grunnskólans og í Noregi er hægt að taka eins árs nám til viðbótar við leikskólakennaranám til að öðlast kennsluréttindi í 1.-4. bekk grunnskólans (Utdanning.no, e.d.). Í Noregi er sérstök námsleið fyrir fólk sem starfar í leikskólum og er hún skipulögð í samvinnu við rekstraraðila leikskóla (no. Arbeidsplassbasert barnehagelærerutdanning). Petta er fjögurra ára nám með vinnu, skipulagt sem fjarnám á netinu, með staðbundnum lotum í háskólum og námi á vinnustaðnum (Utdanning.no, e.d.). Í Svípjóð og í Noregi er kennaramenntun almennt í boði bæði í staðnámi og fjarnámi og hægt að taka námið samhliða vinnu, oftast yfir lengri tíma. Í Finnlandi er einungis boðið upp á hefðbundið staðnám í kennaranámi (European Commission/EACEA/Eurydice, 2019).

Kröfur um hlutfall menntaðra leikskólakennara af starfsfólki leikskóla eru mismiklará Norðurlöndum. Á Íslandi er mælt fyrir um að „að lágmarki $2 / 3$ hlutar stöðugilda við kennslu, umönnun og uppeldi barna í hverjum leikskóla skulu teljast til stöðugilda kennara“ (lög um menntun, hæfni og ráðningu kennara og skólastjórnenda við leikskóla, grunnskóla og framhaldsskóla nr. 95/2019) og hefur slíkt ákvæði verið í lögum síðan 2008 (lög um menntun og ráðningu kennara og skólastjórnenda við leikskóla, grunnskóla og framhaldsskóla nr. 87/2008)1 ${ }^{1}$. Í Svípjóð eru gerðar pær kröfur að a.m.k. einn starfsmaður í hverjum leikskóla sé menntaður leikskólakennari og hann skipuleggi og stýri uppeldisstarfinu, og í Finnlandi parf einn af hverjum premur starfsmönnum leikskóla að vera leikskólakennari (Alila, 2015) en aðrir starfsmenn purfa að hafa framhaldsskólamenntun af uppeldissviði eins og áður kom fram.

Áhugavert er að skoða raunverulega mönnun í leikskólum annars staðar á Norðurlöndum á allra síðustu árum. Í Svípjóð voru árið 2017 40\% starfsfólks í leikskólum með bakkalárpróf í leikskólakennarafræðum, 1,7\% voru með meistarapróf, tæp 10\% höfðu annars konar uppeldismenntun

1 Í 19. gr. laganna stendur: „Ef enginn kennari sækir um auglýst kennslustarf við leikskóla prátt fyrir endurtekna auglýsingu er heimilt að lausráða í starfið til bráðabirgða, að hámarki til eins árs í senn, einstakling sem ekki er kennari. Slíkur starfsmaður má ekki bera starfsheitið kennari og ekki má endurráða hann án undangenginnar auglýsingar. Ákvörðun um ráðningu á grundvelli pessarar málsgreinar er í höndum sveitarstjórnar eða rekstraraðila í tilvikum sjálfstætt rekinna leikskóla." 
úr háskóla, um fimmtungur framhaldsskólamenntun í umönnun barna og um 30\% höfðu enga sérhæfða menntun til að vinna með börnum (European Commission/EACEA/Eurydice, 2019). Í Finnlandi voru 96\% peirra sem höfðu stöðu leikskólakennara með réttindi árið 2016 (Eurydice, e.d.) Árið 2019 var um einn priðji hluti starfsmanna í leikskólum í Noregi leikskólakennarar/ uppeldisfræðingar og um fjórðungur hafði menntun á framhaldsskólastigi á sviði uppeldis og menntunar (Statistics Norway, e.d.). Árið 2018 voru 58\% starfsfólks sem vinnur með börnum í leikskólum í Danmörku með bakkalárpróf í uppeldis- og menntunarfræði/leikskólakennarafræðum, um 30\% með enga menntun á sviði uppeldis og menntunar og 6\% með menntun fyrir aðstoðarfólk í leikskólum (Statistics Denmark, e.d.).

\section{Háskólanemar á 21. öld}

Á síðustu áratugum hafa orðið talsverðar breytingar á peim hópi sem stundar háskólanám í löndum Evrópu og er Îsland par engin undantekning. Mun fleiri fara í háskólanám en ádur og sá hópur sem bæst hefur við er gjarnan fólk sem hefur gert hlé á námi eftir framhaldsskóla til að stunda launavinnu. Pessi hópur stúdenta, 25 ára og eldri, er líklegri til að hafa stofnað fjölskyldu, eiga foreldra með litla formlega menntun og vinna mikið með námi (Masevičiūtė o.fl., 2018). Helmingur allra stúdenta sem tóku pátt Eurostudent-könnuninni, sem náði til 28 landa, vann með námi. Eldri háskólanemar vinna oftast meira en hálfa vinnu samhliða námi og nota minni tíma í námið en stúdentar á hefðbundnum aldri. Hafi foreldrar ekki lokið háskólanámi aukast líkur á að stúdent vinni með náminu og stúdentar í félagsvísindum, hugvísindum og menntavísindum eru líklegri en aðrir til að vinna mikið með námi og líta fremur á sig sem launamann en háskólastúdent.

Samkvæmt niðurstöðum Eurostudent unnu 78\% íslenskra stúdenta með námi og var pað hæsta hlutfallið meðal pátttökulanda. Peir sem unnu með námi unnu að meðaltali 26 tíma á viku á Íslandi en meðaltalið í Evrópu var 28 tímar. Pessi mikla vinna hefur áhrif par sem stúdentar sem unnu meira en 20 klst. á viku notuðu að meðaltali tíu færri stundir í námið en peir sem unnu ekki með námi. Íslenskir stúdentar vinna til að framfleyta sér en yfir $80 \%$ segja svo vera. Peir eru í öðru sæti pjóðanna pegar kemur að svörum við peirri staðhæfingu að peir gætu ekki stundað námið án pess að vinna með pví. 40\% íslenskra stúdenta segjast vinna til að öðlast reynslu á vinnumarkaðinum, sem er lægsta hlutfallið í pátttökulöndunum (Masevičiūtė o.fl., 2018). Fram kom að íslenskir stúdentar 30 ára og eldri sem vinna með námi líta frekar á sig sem launamenn (55\%) en háskólanema meðan peir sem eru 25 ára og yngri líta fyrst og fremst á sig sem stúdenta (95\%). Meðalaldur stúdenta er hæstur, 29 ár á Îslandi, Svípjóð og Finnlandi (Hauschildt, Vögtle og Gwosć, 2018b), en í hlutfallslega flestir íslenskir stúdentar eiga börn (33\%) (Hauschildt, Vögtle og Gwosć, 2018a).

Eins og á Íslandi hefur gengið erfiðlega að laða nógu marga stúdenta til náms íleikskólakennarafræðum í Noregi og Svípjóð. Til að bregðast við pessu hefur t.d. í Noregi verið boðið upp á sérstakar námsleiðir með vinnu (Utdanning.no, e.d.). Í könnun meðal leikskólakennaranema á fyrsta ári í Mittuniversitetet í Svípjóð (Malm, 2017) kom í ljós að 25\% stúdenta voru 30 ára og eldri, yfirgnæfandi meirihluti var konur og næstum helmingur, eða 44\%, stundaði vinnu með námi, $41 \%$ voru með börn á framfæri og 64\% höfðu meira en tveggja ára starfsreynslu í leikskóla. Ljóst er að hefðbundið staðnám hentar illa slíkum nemendahópi.

Á Íslandi hefur verið farin sú leið að bjóða leikskólakennaranám í fjarnámi sem hægt er að taka með vinnu. Pegar haustið 1991 var fjarnám í boði við Fósturskóla Íslands sem viðbrögð við „viðvarandi og vaxandi skorti á fóstrum út um allt land sem hefur lengi verið áhyggjuefni, og er fjarnámið fyrsta raunhæfa tilraun sem gerð hefur verið til úrbóta“ skrifar Puríður Kristjánsdóttir (1995, bls. 1) í úttekt á fyrstu hópunum sem hófu fjarnám árin 1991 og 1993. Tekið var inn í námið annað hvert ár og námið skipulagt sem fjögurra ára nám meðan nám í dagskóla tók prjú ár. Dagskólanemar voru samtals 90 vikur í skólanum í pessi prjú ár en fjarnemar samtals 30 vikur en samskipti pess utan voru í síma og verkefni send í pósti. Tölvusamskipti jukust smám saman en ekki var farið að nota tölvusamskipti að fullu í leikskólakennaranámi fyrr en 1998, eftir tilurð hins nýja Kennaraháskóla Íslands (Auður Kristinsdóttir, Ásrún Matthíasdóttir og M. Allyson Macdonald, 2001). Í pessum fyrstu hópum var 
meðalaldur fjarnema við upphaf náms 33 ár en dagskólanema 24 ár. Margir fjarnemanna höfðu unnið lengi í leikskólum og bjuggu flestir á landsbyggðinni, en pó fimmtungur á höfuðborgarsvæðinu. Pó almennt væri ánægja með námið var kvartað yfir mikilli viðveru í Reykjavík, að tölvusamskipti væru ekki nýtt nægilega vel og einn nemandi sagðist ekki mæla með pessu námi fy rir fólk með heimili og börn (Puríður Kristjánsdóttir, 1995). Eftir sameiningu í Kennaraháskóla Íslands var leikskólakennaranám áfram boðið í fjarnámi og próaðist í takt við fjarnám í grunnskólakennaranámi sem hafði verið í boði frá 1993. Haustið 2007 var meira en helmingur nema í grunnnámi við Kennaraháskóla Íslands í fjarnámi (Guðrún Geirsdóttir o.fl., 2007) og um og yfir helmingur leikskólakennaranema á árunum 2002-2007 var í fjarnámi (Kennaraháskóli Íslands, 2003-2008). Pótt leikskólakennaranámið væri komið á háskólastig var nokkur fjöldi nema áfram tekinn inn á undanpágu frá stúdentsprófi og peir voru fleiri í hópi fjarnema en staðnema, haustið 2000 voru t.d. 62\% fjarnema sem hófu nám með stúdentspróf (Auður Kristinsdóttir o.fl., 2001).

Rannsókn á fyrstu premur árgöngunum (Sif Einarsdóttir og Jóhanna Einarsdóttir, 2002) sem hófu nám á leikskólakennarabraut Kennaraháskóla Íslands árin 1998, 1999 og 2000 leiddi í ljós að 65\% nema höfðu lokið stúdentsprófi og 63\% voru 25 ára og eldri, en rannsóknin snerist ekki um mun á staðnámi og fjarnámi, heldur um aldur nema og ólíkar aðstæður vegna aldurs. Um 70\% nema höfðu reynslu af störfum í leikskóla áður en peir hófu nám. Brottfall úr námi var meira í hópi 25 ára og eldri; priðjungur peirra hætti námi en fimmtungur yngri nema. Petta er í samræmi við rannsóknir sem hafa sýnt að óhefðbundnir háskólanemar eru oft í viðkvæmri stöðu, verr í stakk búnir til að takast á við utanaðkomandi og óvæntar truflanir og eru líklegri til að upplifa kvíða og streitu (Trenz, Ecklund-Flores og Rapoza, 2015), sem getur aukið líkur á brottfalli (Crozier, Reay, Clayton, Colliander og Grinstead, 2008; Delaney og Farren, 2016). Auk pess er pjóðfélagslegur bakgrunnur peirra pannig að peir eru ólíklegri en yngri millistéttarstúdentar til að hafa stuðning frá foreldrum eða fjölskyldu (Delaney og Brown, 2018; Marginson, 2016).

Rannsókn Jóhönnu Einarsdóttur og Sifjar Einarsdóttur (2004) sýnir einnig að hefðbundin kynhlutverk höfðu mikil áhrif varðandi skyldur við fjölskylduna. Jafnframt kemur fram að eldri nemar nálguðust viðfangsefni í námi oft með öðrum hætti en yngri nemar, að móttaka nema í upphafi var mikilvæg, eldri nemar purftu að leita meira til kennara og námsráðgjafa og jákvætt viðmót peirra var mikilvægur liður í að styðja velgengni í náminu. Pá virtist samvinna nema skipta miklu máli. Niðurstöðurnar eru í samræmi við erlendar rannsóknir sem hafa sýnt að tengslanet, félagsauður og félagslegur stuðningur skiptir miklu máli varðandi velgengni nema í námi (Mishra, 2020). Fram kom að reynsla eldri nema af störfum í leikskóla hefði verið dýrmæt í náminu en ekki kemur fram hvort pátttakendur í rannsókninni voru í vinnu með námi. Höfundar telja að niðurstöðurnar veki „spurningar um hvort ekki purfi að laga kennsluhætti á háskólastigi betur að pörfum eldri nema" (Jóhanna Einarsdóttir og Sif Einarsdóttir, 2004).

Jóhanna Einarsdóttir og Sif Einarsdóttir (2004) benda á að ef stefnt sé að pví að efla mannauð í pjóðfélaginu með pví að auka aðgengi óhefðbundinna hópa að háskólanámi purfi að skilja hvers konar stuðning háskólar purfi að veita til að stuðla að góðu gengi í náminu. Fleiri rannsakendur hafa bent á að ekki sé nóg að veita nemum með óhefðbundinn bakgrunn aðgang að námi heldur verði háskólar að sýna vilja og getu til að skipuleggja viðeigandi stuðning sem tekur mið af aðstæðum pessa hóps (Levin, 2007; Puríður Jóhannsdóttir og Amalía Björnsdóttir, 2020). Að veita fleirum aðgang að háskólamenntun hefur í för með sér að koma parf til móts við sérstakar parfir peirra hópa sem annars hefðu ekki haft tækifæri til háskólamenntunar, vegna aðstæðna sinna sem oftast skýrast af stéttarstöðu (Lee, 2017). Í háskólum par sem slíkur stuðningur hefur verið veittur hefur pað skilað sér í jákvæðum áhrifum á framvindu náms (Delaney, 2015). Pessi hópur háskólastúdenta upplifir hins vegar oft að háskólinn sýni peim minni stuðning en hefðbundnum ungum stúdentum og jafnvel að peir gleymist (Delaney og Brown, 2018).

Markmiðið með rannsókninni sem hér er kynnt var annars vegar að meta pörf fyrir leikskólakennara á Íslandi og hins vegar að skoða stöðu leikskólakennaramenntunar við Háskóla Íslands. Leitað var skýringa á hvers vegna svo fáir hafa verið brautskráðir með leikskólakennararéttindi síðustu ár, p.e. síðan meistaranám purfti til að öðlast réttindi. Rannsóknarspurningarnar voru: 
1. Hver er pörf fyrir nýliðun í stétt leikskólakennara?

a. Miðað við að hlutfall leikskólakennara verði sambærilegt og pað er núna?

b. Miðað við að hlutfall leikskólakennara verði í samræmi við gildandi lög?

2. Hver er staðan í leikskólakennaranáminu við Háskóla Íslands?

a. Hversu margir stunda nám og hversu margir hafa lokið prófgráđum íleikskólakennaranámi, B.Ed. og M.Ed.?

b. Hver er bakgrunnur og hvernig eru aðstæður leikskólakennaranema við Háskóla Íslands?

\section{Аðferð}

Gagnasöfnun var prípætt, í fyrsta lagi var unnið upp úr gögnum Hagstofu Íslands um fjölda leikskólabarna, einkenni barnahópsins og lengd skóladags á tímabilinu 1998-2018. Auk pess var upplýsingum safnað um fjölda og aldur leikskólakennara á sama tímabili svo og brautskráningar úr leikskólakennaranámi. İ öðru lagi voru unnar úr opinberum skýrslum upplýsingar um fjölda leikskólakennaranema og brautskráningar við Háskóla Íslands. Í priðja lagi var gögnum safnað með rafrænni könnun meðal leikskólakennaranema.

\section{Pátttakendur}

Pátttakendur í spurningakönnun voru fyrsta árs nemar í fimm ára leikskólakennaranámi við Menntavísindasvið Háskóla Íslands sem hófu nám haustið 2018 ( $N=48)$ og 2019 ( $N=38)$. Fjarnemar voru 66 (77\%), staðnemar 19 (22\%) og einn nemi sagðist vera í blöndu af stað- og fjarnámi. Auk nema á fyrsta námsári var upplýsingum safnað frá nemum á öðru námsári haustið $2019(N=40)$. Í hópi annars árs nema voru fjarnemar 35 (88\%), staðnemar tveir (5\%) og prír (8\%) voru í blöndu af stað- og fjarnámi. Allir annars árs nemar sem sögðust hafa verið í fjarnámi á fyrsta námsári voru áfram í fjarnámi en prír höfðu fært sig úr staðnámi yfir í fjarnám.

Pátttakendur voru spurðir um kyn pegar peir svöruðu á fyrsta námsári og voru konur 88\% pátttakenda. Hópurinn sem var á öðru námsári haustið 2019 hafði tekið pátt pegar hann var á fyrsta námsári 2018 svo að ekki var aftur aflað upplýsinga um kyn.

\section{Mælitækið}

Pátttakendur voru í spurningakönnun spurðir um bakgrunn sinn, meðal annars kyn, aldur, fyrri menntun og menntun foreldra. Einnig voru spurningar sem sneru að fyrri reynslu á vinnumarkaði; spurt um reynslu af vinnu í leikskólum, grunnskólum, í tómstundastarfi eða með fötluðu fólki. Spurt var um vinnu með námi, bæði við hvað var unnið og hversu margar klukkustundir á viku. Nokkrar spurningar sneru að páttum sem gætu haft neikvæð áhrif á nám. Að lokum var kannað hvort pátttakendur væru fjarnemar, staðnemar eða tækju námskeið bæði í fjar- og staðnámi. Spurningakönnunin var samin af rannsakendum.

\section{Framkvæmd}

Gagnasöfnun vegna spurningakannananna fór fram í október árið 2018 og 2019. Nemar voru heimsóttir í staðlotu og könnunin kynnt, bent á aðgang að henni á netinu og hvatt til pátttöku. Einnig fengu nemar hvatningu í tölvupósti frá kennurum í námskeiðum sem peir sóttu. Pátttakendum var greint frá að ekki væri skylda að svara spurningakönnuninni, að sleppa mætti einstökum spurningum og aðeins annar rannsakenda hefði aðgang að gögnunum. 
SPSS 26 var notað við gagnagreiningu. Reiknuð var lýsandi tölfræði og tengsl skoðuð með Fisher Exact-prófi, sem hentar vel pegar hópar eru fámennir og skilyrði um notkun kí-kvaðrat eru ekki uppfyllt (Field, 2018). Áhrifsstærð tengsla var metin með Cramer V.

\section{Niðurstöður}

\section{Fjöldi leikskólabarna og 1 eikskólakennara}

Til að meta pörf fyrir leikskólakennara voru notaðar upplýsingar frá Hagstofu Íslands frá tímabilinu 1998-2018 (Hagstofa Íslands, 2020b) og var skoðaður fjöldi leikskólabarna, dvalartími og aldur barnanna. Flest voru leikskólabörnin árið 2014, pá voru 19.938 börn í íslenskum leikskólum, en fæst voru pau árið 1999, eða 14.761.

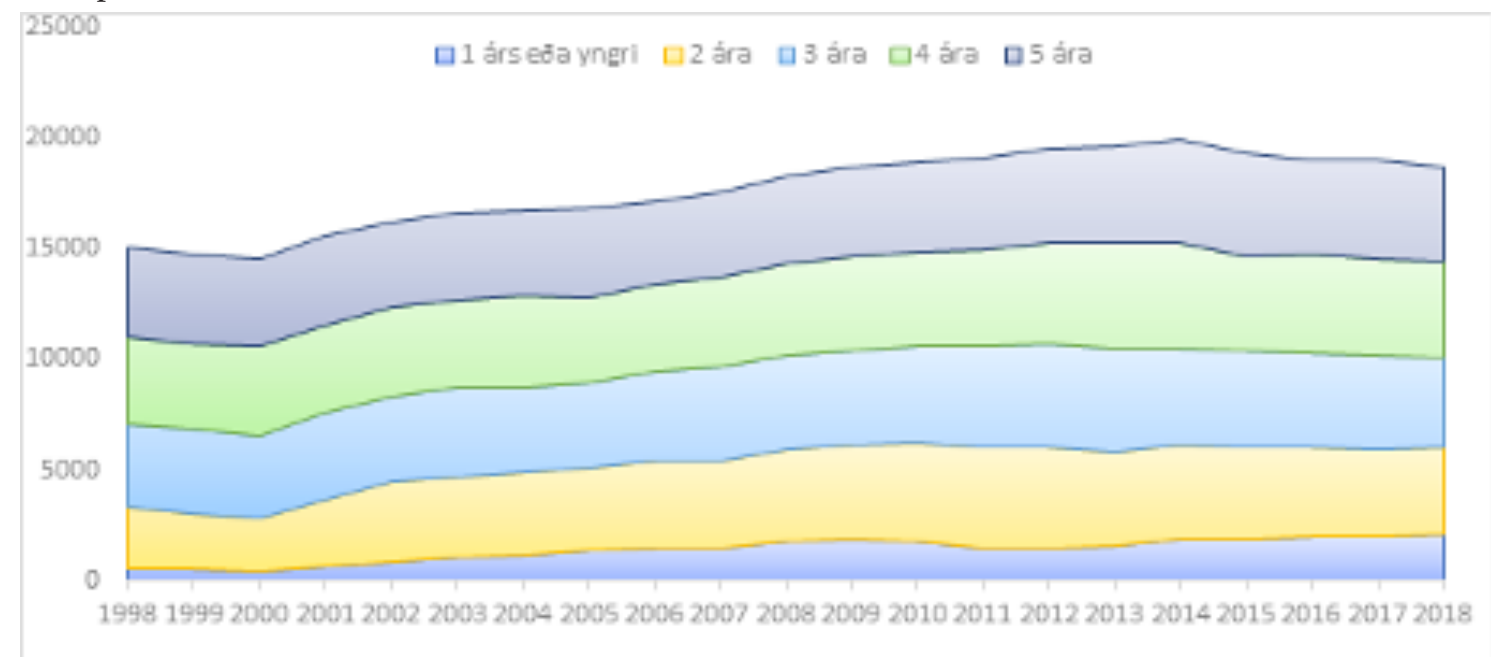

Mynd 1. Fjöldi leikskólabarna eftir aldri.

Af Mynd 1 má ráða að fjölgun leikskólabarna er fyrst og fremst að rekja til fjölgunar í hópi eins og tveggja ára barna. Frá 1998 til 2018 fjölgaði leikskólabörnum um 3.635. Í hópi barna eins árs og yngri fjölgaði peim um 1.582 og um 1.504 í hópi tveggja ára barna. Á sama tíma hefur skóladagur leikskólabarna lengst, sjá Mynd 2 (Hagstofa Íslands, 2020b).

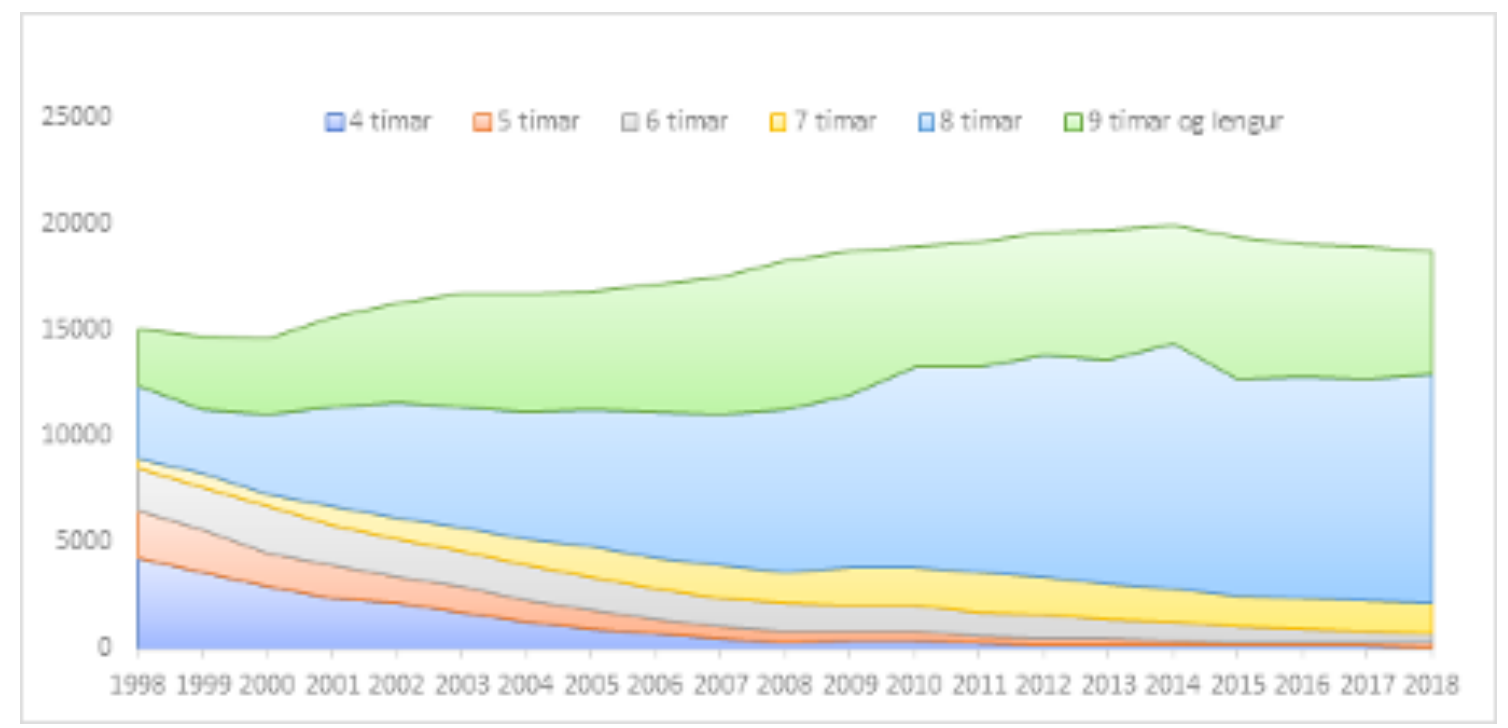

Mynd 2. Lengd viðveru í leikskólum 1998 til 2018. 
Á Mynd 2 sést yfirlit yfir dvalartíma leikskólabarna frá 1998 til 2018. Á pessu tímabili hefur skóladagurinn lengst, pannig voru 43\% barna í fjóra til fimm tíma í leikskóla árið 1998 en aðeins 1\% árið 2018. Árið 1998 voru 40\% leikskólabarna í skólanum í átta klst. eða lengur en hlutfallið var 89\% árið 2018. Á tímabilinu 1998-2018 urðu einnig breytingar á samsetningu nemendahópsins, en börnum með annað móðurmál en íslensku og peim sem purfa sérstakan stuðning fjölgaði. Árið 1998 voru 572 börn með erlent móðurmál í leikskólum en eru orðin 2.570 árið 2018. Börnum sem veittur var sérstakur stuðningur fjölgaði einnig, úr 553 árið 1998 í 1.888 árið 2018.

Hagstofa Íslands notar svokölluð barngildi til að meta starfsmannapörf leikskóla út frá aldri og dvalartíma leikskólabarna. Pannig reiknast fimm ára barn sem er allan daginn í leikskólanum sem 0,8 barngildi, fjögurra ára barn sem 1,0 barngildi, priggja ára barn sem 1,3 barngildi, tveggja ára barn sem 1,6 barngildi og barn sem er yngra en tveggja ára sem 2,0 barngildi. Barngildi í leikskólum voru 14.179 árið 1998 en 23.204 árið 2018 (Hagstofa Íslands, 2020b).

Opinber viðmið gera ráð fyrir að tveir priðju hlutar starfsmanna í íslenskum leikskólum séu leikskólakennarar og á Mynd 3 sést fjöldi starfsmanna í leikskólum eftir menntun á 20 ára tímabili frá 1998 (Hagstofa Íslands, 2020b).

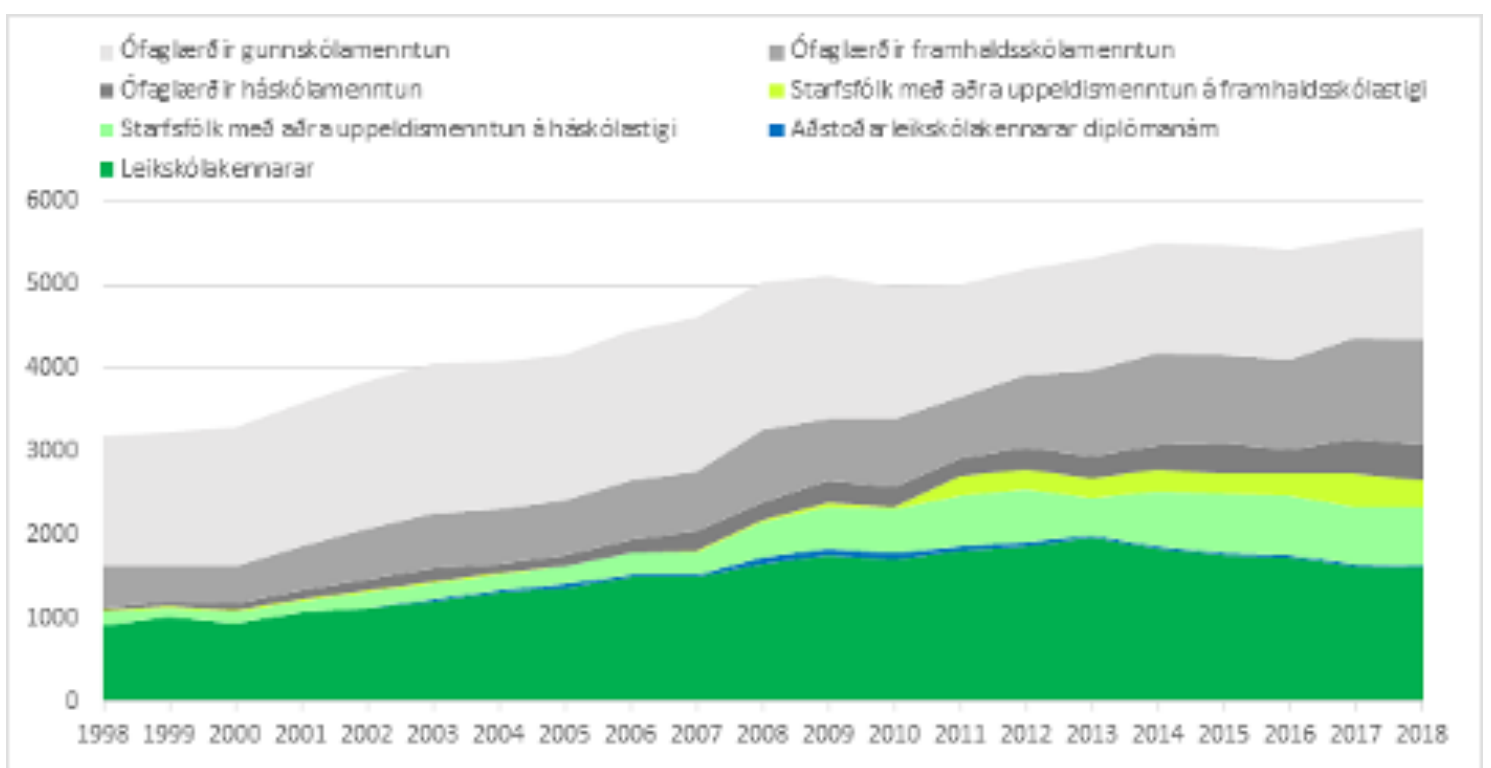

Mynd 3. Starfsfólk leikskóla sem sinnir uppeldi og menntun barna, eftir menntun.

Árið 1998 voru 930 leikskólakennarar starfandi í leikskólum en peim hafði fjölgað í 1.600 árið 2018 (sjá Mynd 3). Árið 1998 eru peir 29\% af starfsmönnum sem sinna uppeldi og menntun í leikskólum en 28\% árið 2018. Hæst var hlutfall leikskólakennara árin 2011 og 2012 en pá voru peir 36\% starfsmanna. Örfáir aðstoðarleikskólakennarar sem lokið hafa tveggja ára diplómanámi starfa í leikskólum, urðu flestir 68 árið 2010. Starfsmenn með uppeldismenntun á háskólastigi aðra en leikskólakennaramenntun voru 12\% starfsmanna árið 2018 en aðeins 4\% árið 1998 og mjög fáir starfsmenn eða 6\% voru með uppeldismenntun á framhaldsskólastigi árið 2018. Árið 2018 var yfir helmingur starfsmanna (53\%) ekki með neina menntun á sviði uppeldis og menntunar og mikil hreyfing var á starfsfólki leikskóla (Hagstofa Íslands, 2020b). Á tímabilinu 1998-2018 voru að meðaltali $11 \%$ leikskólakennara ekki við störf ári síðar, en hlutfallið var $28 \%$ hjá öðrum uppeldismenntuðum starfsmönnum og 32\% hjá ófaglærðum.

Frá 2012 hefur leikskólakennurum í hópi starfsfólks leikskóla fækkað og hlutfall eldri leikskólakennara í stéttinni hefur aukist, sjá Mynd 4 (Hagstofa Íslands, 2020a). 


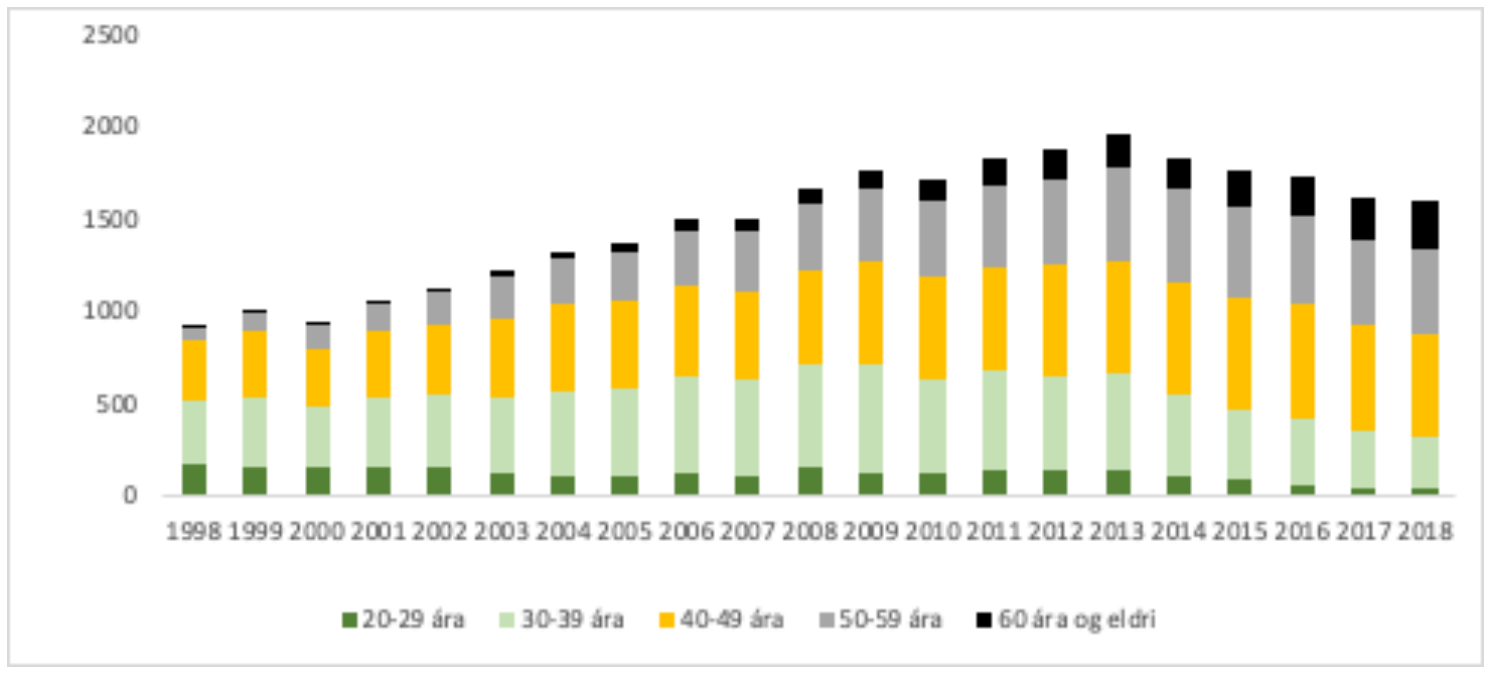

Mynd 4. Aldur leikskólakennara.

Árið 1998 voru 930 leikskólakennarar starfandi í íslenskum leikskólum og voru 520, eða 56\%, peirra undir fertugu en árið 2018 eru 314 af 1.600 starfandi leikskólakennurum á pessum aldri, eða 20\% (sjá Mynd 4). Leikskólakennurum 60 ára og eldri hefur fjölgað á sama tíma úr 14 í 267, eða úr 1,5\% upp í 17\% starfandi leikskólakennara og fjöldi leikskólakennara 50 ára og eldri árið 2018 er 730 . Til að fylla í skörð peirra sem fara á eftirlaun parf að útskrifa um 27 leikskólakennara á ári á tímabilinu 2019 til 2028 og næstu tíu árin par á eftir parf að útskrifa 47 á ári til að fylla í skarð peirra sem verða 70 ára.

Yfirlit um fjölda útskrifaðra leikskólakennara á skólaárinu 1997-1998 til 2017-2018 má sjá á Mynd 5 (Hagstofa Íslands, 2020a) en tveir háskólar mennta leikskólakennara, Háskóli Íslands og Háskólinn á Akureyri.

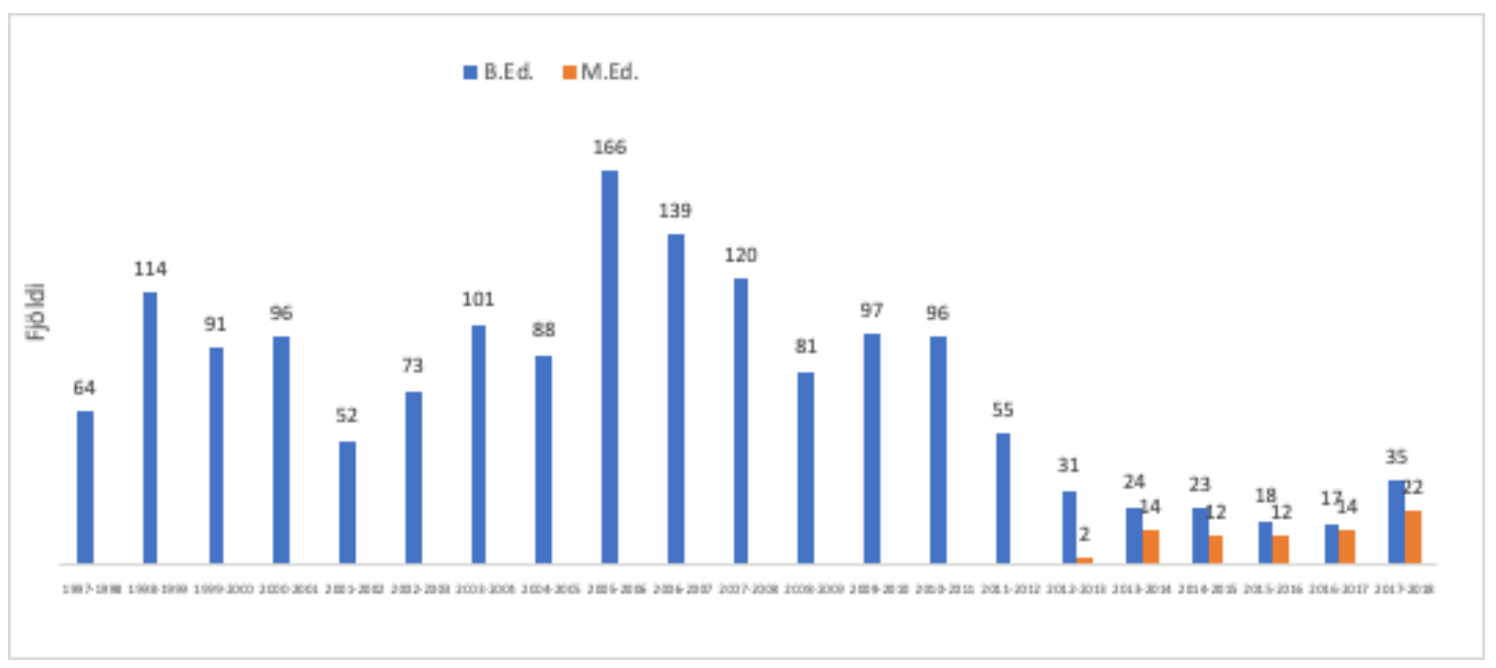

Mynd 5. Fjöldi útskrifaðra nema með B.Ed.- og M.Ed.-gráðu.

Á Mynd 5 sést að nokkrar sveiflur eru í fjölda útskrifta úr B.Ed.-námi í leikskólakennarafræðum. Meðan bakkalárgráða veitti leikskólakennararéttindi útskrifuðust flestir skólaárið 2005-2006, eða 166. Fram til 2011, pegar bakkalárgráða var nægjanleg til starfsréttinda, útskrifuðust að meðaltali 98 á ári en eftir að farið var að krefjast meistaragráðu luku 29 bakkalárprófi á ári. Síðan 2011 hafa peir sem ljúka meistaraprófi til leikskólakennararéttinda verið að meðaltali 15 á ári og flestir 22 skólaárið 2017-2018. 


\section{Fjöldi leikskólakennaranema við Háskóla Íslands}

Til að svara hversu margir stunda nám og hversu margir hafa lokið prófgráðum íleikskólakennaranámi frá Háskóla Íslands, var byggt á upplýsingum úr HÎ í tölum (Háskóli Îslands, 2020).

Tafla 1. Fjöldi leikskólakennaranema og brautskráningar frá Háskóla Íslands

\begin{tabular}{lcccccc}
\hline & \multicolumn{2}{c}{$\begin{array}{c}\text { B.Ed.-gráda í } \\
\text { leikskólakennarafræðum }\end{array}$} & \multicolumn{2}{c}{$\begin{array}{c}\text { M.Ed.-gráða í } \\
\text { leikskólakennarafræðum }\end{array}$} & \multicolumn{2}{c}{$\begin{array}{c}\text { M.Ed.-gráda í } \\
\text { menntunarfræði leikskóla }{ }^{3}\end{array}$} \\
\hline Ár & Skráðir nemar & Útskrifaðir & Skráðir nemar & Útskrifaðir & Skráðir nemar & Útskrifaðir \\
\hline 2010 & 184 & 80 & 0 & 0 & 0 & 0 \\
2011 & 93 & 76 & 0 & 0 & 0 & 0 \\
2012 & 76 & 27 & 13 & 0 & 0 & 0 \\
2013 & 77 & 24 & 22 & 2 & 0 & 0 \\
2014 & 66 & 14 & 26 & 8 & 19 & 0 \\
2015 & 88 & 18 & 28 & 7 & 46 & 1 \\
2016 & 86 & 11 & 29 & 3 & 58 & 8 \\
2017 & 102 & 12 & 26 & 6 & 57 & 8 \\
2018 & 124 & 19 & 31 & 4 & 62 & 15 \\
2019 & 147 & 21 & 35 & 6 & 76 & 14 \\
2020 & 175 & & 26 & & 40 & \\
\hline
\end{tabular}

1 Tölur Háskóla Íslands miðast við almanaksár en Hagstofa Íslands skoðar útskriftir út frá skólaári (sjá Mynd 5).

${ }^{2}$ Meistaragráða fyrir pá sem lokið hafa B.Ed. gráðu í leikskólafræðum.

${ }^{3}$ Meistaragráða fyrir pá sem lokið hafa bakkalárgráðu í öðru fagi en leikskólakennarafræði (sjá nánar um hópinn í Amalía Björnsdóttir og Puríður Jóna Jóhannsdóttir, 2020).

${ }^{4}$ Miðað er við fjölda skráðra nema 1. október ár hvert.

Á fimm ára tímabili frá 2015 til 2019 voru að meðaltali 109 stúdentar skráðir í leikskólakennaranám til B.Ed.-gráðu en 16 að meðaltali luku námi. Ef brottfall væri ekkert og allir lykju námi á premur árum pá ætti um priðjungur hópsins að ljúka bakkalárprófi árlega en hlutfallið var ekki nema 15\%. Námstími er pví annaðhvort langur eða brottfall mikið en tölur um brottfall á milli ára liggja ekki fyrir. Staðan var svipuð í meistaranáminu en á tímabilinu 2015-2019 voru að meðaltali um 30 nemar skráðir í meistaranám í leikskólakennarafræði en fimm útskrifuðust árlega. Ef námstími væri innan ráðgerðra tímamarka og brottfall ekkert ætti helmingur að brautskrást á ári en aðeins 17\% luku námi. Fyrstu stúdentarnir innrituðust í meistaranám í menntunarfræði leikskóla árið 2014 og síðan hafa um helmingi fleiri verið innritaðir á pessa leið en peir sem eru í fimm ára leikskólakennaranámi. Hlutfall leikskólakennara sem útskrifast af pessari leið er svipaður en 2017-2019 útskrifast um 19\% árlega af peim hóp sem er innritaður.

\section{Bakgrunnur og aðstæður leikskólakennaranema við Háskóla Íslands}

Til að kanna bakgrunn og aðstæður leikskólakennaranema við Háskóla Íslands var spurningalistakönnun lögð fyrir nema sem voru að hefja nám. Af 86 pátttakendum á fyrsta námsári voru konur 76 (88\%), karlar 10 (11\%) og einn merkti við annað (1\%). 


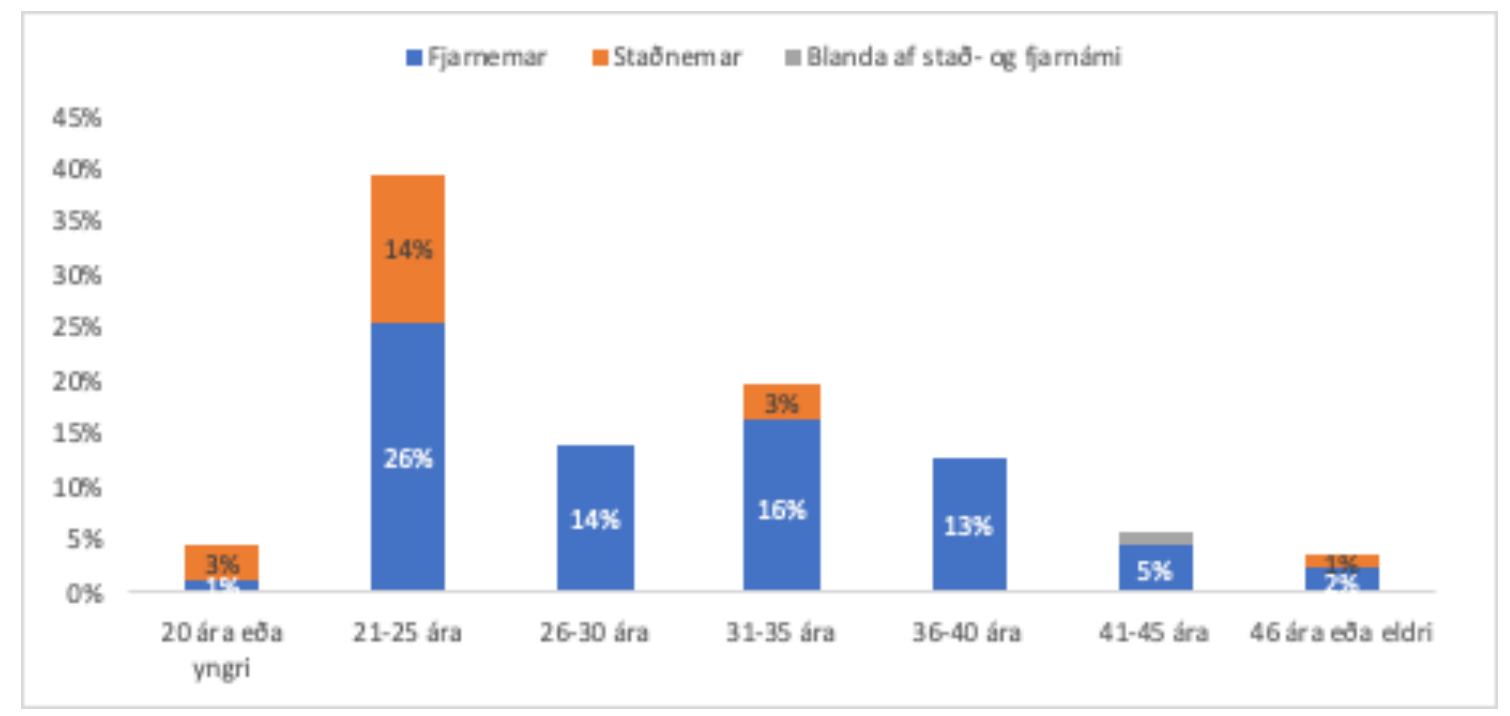

Mynd 6. Aldur stað- og fjarnema.

Um 55\% nema á fyrsta námsári voru yfir 25 ára aldri og 21\% var yfir 35 ára aldri (sjá Mynd O). Yfirlit yfir aldur eftir námsformi má sjá á Mynd 6. Marktæk tengsl voru á milli aldurs og námsforms (Fisher Exact $p=0,004$, Cramer V =0,46). Tæp 80\% staðnema voru 25 ára og yngri en $35 \%$ fjarnema. Meira en fjórðungur fjarnema var 36 ára og eldri pegar peir hófu B.Ed.-nám í leikskólakennarafræðum.

Af pátttakendum voru $61 \%$ í sambúð, hlutfall fjarnema í sambúð var $71 \%$ en $26 \%$ staðnema voru í sambúð (Fisher Exact $p=0,001$, Cramer V =0,38). Um 45\% pátttakenda voru barnlaus, um 20\% voru með eitt barn á heimilinu, um fjórðungur var með tvö börn og um $10 \%$ voru með prjú eða fleiri börn. Staðnemar voru miklu líklegri til að vera barnlausir (83\%), en 36\% fjarnema voru barnlaus (Fisher Exact $p=0,005$, Cramer $\mathrm{V}=0,39$ ).

Af öllum nemum á fyrsta námsári bjuggu um 70\% á höfuðborgarsvæðinu. Fjórðungur bjó á Suðurnesjum, Vesturlandi og Suðurlandi, svæðum par sem að minnsta kosti hluti hópsins er í innan við klukkustundar akstursfjarlægð frá háskólasvæðinu.

Ekki voru tengsl á milli búsetu og pess að vera í stað- eða fjarnámi (Fisher Exact $p=0,71$, Cramer V $=0,21) .65 \%$ fjarnema bjuggu á höfuðborgarsvæðinu og $4 \%$ til viðbótar á Suðurnesjum í hæfilegri akstursfjarlægð frá háskólasvæðinu. Aðeins 7\% bjuggu á svæðum sem segja má með vissu að séu utan hæfilegrar akstursfjarlægðar frá háskólasvæðinu, pað er á Norður- og Austurlandi. Af staðnemum bjuggu $84 \%$ á höfuðborgarsvæðinu, $11 \%$ á Vesturlandi og $5 \%$ á Suðurlandi. Í raun var pað svo að nærri helmingur (48\%) allra nema á fyrsta ári í leikskólakennarafræðum var fjarnemar sem bjuggu á höfuðborgarsvæðinu.

Um 70\% nema á fyrsta námsári höfðu lokið stúdentsprófi. Algengara var að staðnemar hefðu lokið stúdentsprófi, $90 \%$ á móti $64 \%$ fjarnema (Fisher Exact $p=0,046$, Cramer V =0,23). Flestir höfðu íslensku að móðurmáli, eða $90 \%$ leikskólakennaranema, og ekki voru tengsl á milli námsforms og pess að eiga íslensku að móðurmáli (Fisher Exact $p=0,37$, Cramer $\mathrm{V}=0,12$ ).

Tengsl voru milli námsforms og menntunar móður nemanna (Fisher Exact $p=0,009$, Cramer $\mathrm{V}$ $=0,39) .28 \%$ allra pátttakenda áttu móður sem ekki hafði lokið frekara námi en grunnskólaprófi; hlutfallið var 32\% hjá fjarnemum og 16\% hjá staðnemum. Af öllum pátttakendum áttu $28 \%$ móður sem lokið hafði háskólaprófi og átti pað við um 19\% fjarnema og 58\% staðnema. Aftur á móti voru ekki tengsl milli námsforms og menntunar föður (Fisher Exact $p=0,35$, Cramer $\mathrm{V}=0,22$ ), en áberandi var hversu margir nemar áttu föður með iðn- eða starfsmenntun, eða 42\% fjarnema og $39 \%$ staðnema. 


\section{Starfsreynsla og vinna með námi}

Nemar á fyrsta námsári höfðu margs konar starfsreynslu. Pannig höfðu 19\% peirra unnið í grunnskóla, 11\% í frístundastarfi og 9\% við ípróttapjálfun en langflestir, eða 94\%, höfðu reynslu af starfi í leikskóla. Tengsl voru á milli námsforms og starfsreynslu í leikskólum (Fisher Exact $p=0,05$, Cramer V = 0,31). Aðeins 3\% fjarnema og 16\% staðnema höfðu enga reynslu af vinnu í leikskóla en 83\% fjarnema og 53\% staðnema höfðu unnið par í tvö ár eða lengur.

Í upphafi náms á fyrsta námsári sögðust $90 \%(N=77) \mathfrak{x t l a ~ a ð ~ v i n n a ~ m e ð ~ n a ́ m i , ~} 9 \%(N=8)$ svöruðu pví neitandi. Fjarnemar voru líklegri til að ætla að vinna með námi, 95\% peirra svöruðu pví játandi en $68 \%$ staðnema (Fisher Exact $p=0,003$, Cramer V = 0,38).

Stór hluti leikskólakennaranemanna á fyrsta námsári vann mikið með náminu. Af öllum hópnum vann helmingur hópsins 31 klst. á viku eða meira, voru peir allir fjarnemar nema tveir og aðeins $10 \%$ hópsins unnu ekki með námi. Tengsl milli námsforms og vikulegs vinnutíma voru sterk (Fisher Exact $\mathrm{p}<0,001$, Cramer V = 0,75). Pegar komið var á annað námsár unnu 73\% hópsins í 31 klst. eða meira á viku.

Af peim 77 fyrsta árs nemum sem svöruðu við hvað peir störfuðu unnu 72 (94\%) sem leiðbeinendur í leikskóla. Allir fjarnemar voru leiðbeinendur í leikskóla eða í starfi tengdu náminu en 77\% staðnema (Fisher Exact $\mathrm{p}<0,009$, Cramer V = 0,45). Alls 95\% nema á öðru námsári voru að vinna og allir sem leiðbeinendur í leikskóla fyrir utan einn sem sagðist vera í starfi sem tengdist námi hans.

\section{Tími sem varið er í námið, einingaföldi og pættir sem hafa áhrif á námið}

Meirihluti nema (71\%) var skráđur í sem samsvarar fullu námi, eða 26 einingar eða meira á fyrsta námsári. Pó heldur fleiri staðnemar hafi hafi talist í fullu námi (89\%) en fjarnemar (65\%) voru ekki marktæk tengsl á milli einingafjölda og námsforms (Fisher Exact $p=0,65$, Cramer V =0,19). Pegar nemar á öðru ári voru spurðir um einingafjölda sem peir luku á fyrsta námsári höfðu 40\% lokið 51-60 ECTS-einingum, sem samsvarar fullu námi, en 30\% tóku 30 ECTS-einingar eða minna, sem samsvarar hálfu námi.

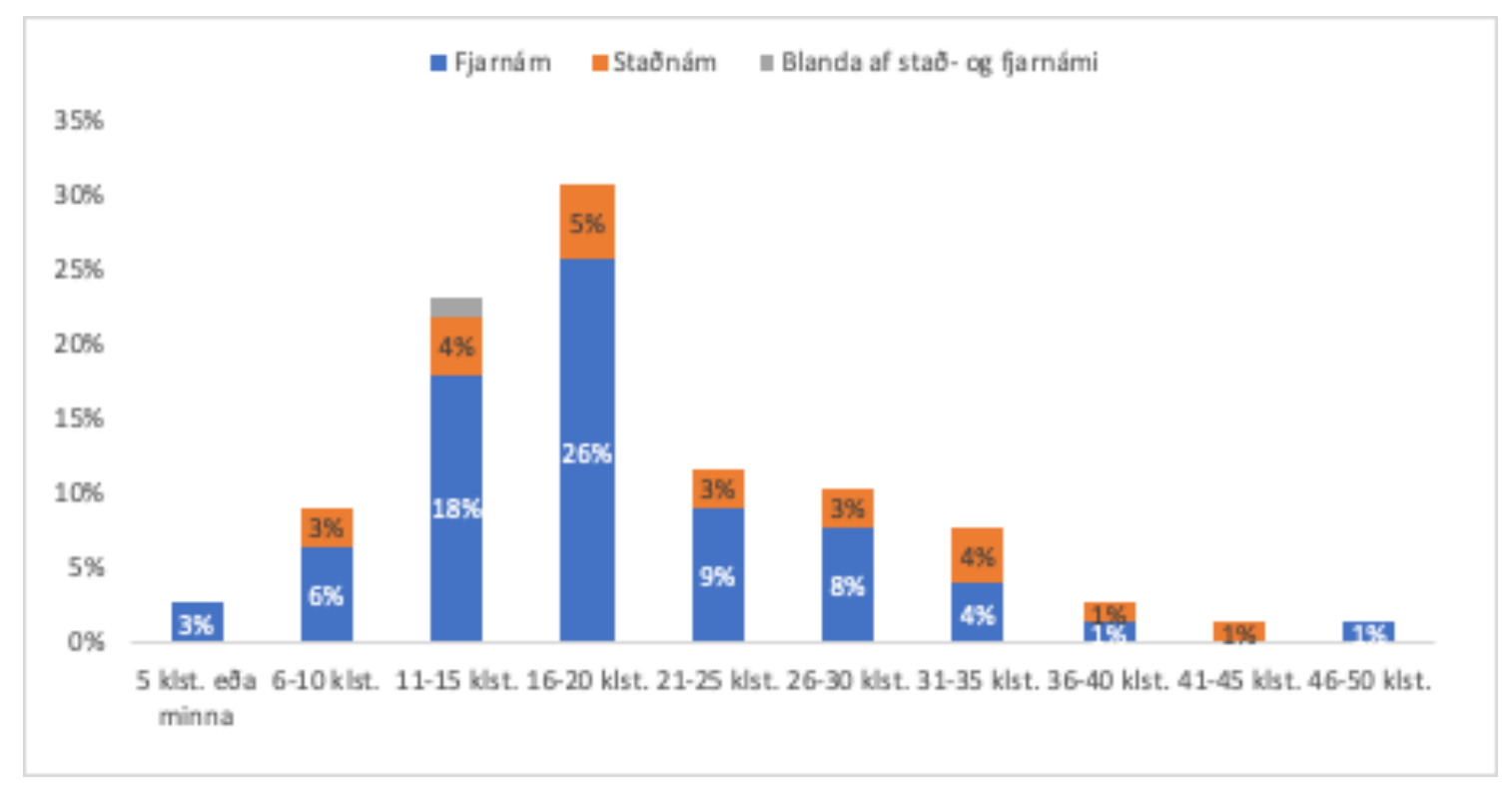

Mynd 7. Tími sem nemar nota í allt nám á viku. 
Pátttakendur voru beðnir að meta hversu mikinn tíma peir notuðu í námið á viku (sjá Mynd 7). Telja átti með allan tíma sem færi í að sækja eða hlusta á fyrirlestra, vinna verkefni og í heimanám. Langflestir, eða 54\% pátttakenda, notuðu 11 til 20 klst. á viku í námið (sjá nánar Mynd 7) en fáir, eða um 5\%, notuðu 36 klst. á viku eða meira. Ekki voru tengsl á milli námsforms og tíma sem notaður var í námið (Fisher Exact $p=0,487$, Cramer V =0,33) en samanburður er flókinn par sem fjarnemar luku færri einingum á misseri en staðnemar.

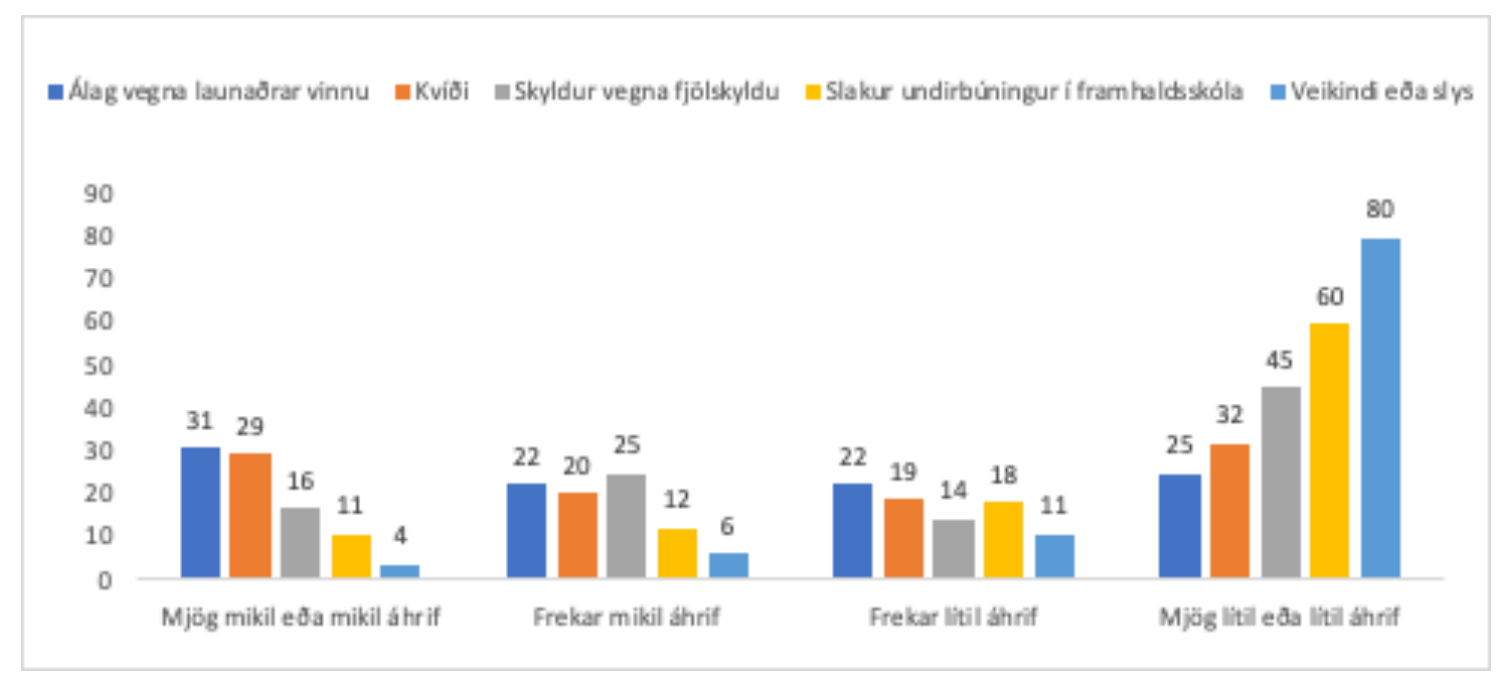

Mynd 8. Pættir sem hafa neikvæð áhrif á nám leikskólakennaranema.

Á Mynd 8 má sjá svör pátttakenda við hversu mikil neikvæð áhrif ákveðnir pættir hefðu á nám peirra í leikskólakennarafræðum. Svör voru endurskilgreind pannig að svarkostirnir mjög mikil og mikil voru teknir saman og einnig svarkostirnir mjög lítil og lítil. Enginn munur var á svörum stað- og fjarnema. Um 31\% pátttakenda taldi að álag vegna launaðrar vinnu hefði mjög mikil eða mikil neikvæð áhrif á nám sitt og 29\% töldu slíkt eiga við um kvíða. Fáir töldu veikindi og slys (4\%) eða slakan undirbúning í framhaldsskóla (11\%) hafa mjög mikil eða mikil neikvæð áhrif en 16\% sögðu skyldur vegna fjölskyldu hafa slík áhrif.

\section{Samantekt og umræða}

Tilgangur rannsóknarinnar var að meta pörf fyrir leikskólakennara og skoða stöðu leikskólakennaramenntunar við Háskóla Íslands með tilliti til fjölda útskrifaðra og aðstæðna nema. Á tímabilinu 1998 til 2013, í kjölfar pess að námið var fært á háskólastig og kennsla hófst við Háskólann á Akureyri, fjölgaði leikskólakennurum jafnt og pétt. Öflugt fjarnám bætti möguleika óhefðbundinna stúdenta til náms en meirihluti leikskólakennaranema í fyrstu árgöngum í Kennaraháskóla Î́slands var í peim hópi (Auður Kristinsdóttir o.fl., 2001; Sif Einarsdóttir og Jóhanna Einarsdóttir, 2002). Prátt fyrir að leikskólakennurum fjölgaði mikið á fyrsta áratug 21. aldar pá hækkaði ekki hlutfall leikskólakennara af starfsfólki leikskóla sem neinu næmi, varð hæst 36\% árin 2011 og 2012 en er nú tæp 30\%, eins og var fyrir tuttugu árum. Skýringin er mikil fjölgun í hópi yngstu barnanna í leikskólum og lenging skóladagsins, sem hefur kallað á miklu fleira starfsfólk.

Ef litið er á aldur leikskólakennara sem voru í starfi árið 2018 pá voru 730 peirra komnir yfir fimmtugt. Ef gert er ráð fyrir að peir vinni allir til sjötugs parf að útskrifa 37 leikskólakennara á ári að meðaltali næstu tuttugu árin einungis til að viðhalda peim fjölda sem nú starfar í leikskólum landsins. Ef ná ætti að manna tvo priðju starfa með leikskólakennurum eins og lögin kveða á um pyrfti hins vegar á næstu 20 árum að útskrifa yfir 150 leikskólakennara á ári. Hér er gengið út frá peim forsendum að barnafjöldi verði svipaður og að allir útskrifaðir leikskólakennarar vinni til sjötugs sem eru pó hæpnar forsendur pví til að mynda fækkaði starfandi leikskólakennurum um 72 
á ári á tímabilinu 2013-2018 sem sýnir að peir hverfa úr starfi af öðrum ástæðum en vegna aldurs. Pað parf pví að meira en tífalda pann fjölda sem háskólarnir hafa brautskráð síðustu ár eigi markmið laganna að nást fyrir árið 2040. Pó fjölga purfi peim sem hefja nám í leikskólakennarafræðum pá parf ekki síður að styðja við pá sem hefja námið. Á tímabilinu 2015-2019 hafa að meðaltali 90 nemar verið í meistaranámi í leikskólakennarafræði við Háskóla Íslands og af peim fjölda hafa um 12 lokið námi á ári. Vandamálið er pví tvípætt; of fáir stúdentar hefja nám en auk pess er námsframvinda peirra sem hefja námið hæg og/eða brottfall mikið.

Meirihluti stúdenta á fyrsta ári í grunnnámi í leikskólakennarafræðum sem pátt tóku í pessari rannsókn var 25 ára og eldri og tilheyrir hópi óhefðbundinna stúdenta. Fyrri rannsóknir hafa sýnt að peir eru í viðkvæmari stöðu og eru t.d. líklegri til að seinka eða hætta í námi vegna ytri aðstæðna (Crozier o.fl., 2008; Delaney og Farren, 2016; Trenz o.fl., 2015). Óhefðbundnir stúdentar eru líklegri til að eiga foreldra með stutta skólagöngu og stéttarstaða peirra hefur ráðið miklu um að peir fóru ekki beint í háskólanám eftir framhaldsskóla par sem peir hafa purft að vinna fyrir sér (Delaney og Farren, 2016). Niðurstöður pessarar rannsóknar eru í samræmi við petta og gæti petta skýrt hversu lágt hlutfall peirra sem innritast í leikskólakennaranám ljúka námi. Ekki liggja fyrir upplýsingar um brottfall í leikskólakennaranámi við Háskóla Íslands en mikilvægt væri að vita hvenær brottfall á sér stað og hvað námstími er í raun langur til að hægt sé að bregðast við og stuðla að pví að peir sem hafa áhuga á að verða leikskólakennarar geti lokið námi.

Val á fjarnámsforminu hjá pátttakendum hér tengist fremur aldri og aðstæðum en búsetu. Petta er í samræmi við erlendar rannsóknir (Delaney, 2015) sem hafa leitt í ljós að fjarnám hentar eldri háskólanemum vegna pess að pað gefur peim kost á að ráða á hvaða tíma peir sinna náminu og gerir peim par með mögulegt að stunda nám samhliða vinnu og skyldum við fjölskyldu. Erlendar rannsóknir (Delaney, 2015) hafa leitt í ljós að fjarnemar eru oft í hálfu starfi eða meira og pað á við um leikskólakennaranema við Háskóla Íslands. Mikill meirihluti peirra hefur unnið í leikskóla áður en peir hefja námið, stór hluti vinnur mikið með náminu og langflestir sem leiðbeinendur í leikskóla. Ætla má að leikskólakennaranemar séu verðmætir starfsmenn í leikskólum par sem menntunin er líkleg til að styrkja fagmennsku peirra og mikill skortur er á leikskólakennurum. Öflugt fjarnám sem hentar með vinnu er pví lykilatriði til að mæta pörfum pessa hóps.

Um fjórðungur stúdenta í fyrstu árgöngum í leikskólakennaranámi í Kennaraháskólanum hætti námi á fyrsta námsári (Sif Einarsdóttir og Jóhanna Einarsdóttir, 2002). Рað ætti ekki að koma á óvart ef brottfall væri talsvert meðal leikskólakennaranema sem nú eru í námi par sem álag myndast við að vera í námi samhliða launuðu starfi og skyldum við fjölskyldu. Pátttakendur töldu að mikil vinna hefði neikvæð áhrif á framvindu námsins en rúmlega helmingur sagði vinnuna hafa frekar mikil eða mikil neikvæð áhrif. Rétt tæpur helmingur nefndi að kvíði hefði neikvæð áhrif á námið. Aðstæður stúdenta sem hafa skyldum að gegna vegna náms, vinnu og fjölskyldu eru líklegar til að valda togstreitu milli ólíkra hlutverka og par með kvíða. Erlendar rannsóknir hafa sýnt að óhefðbundnir háskólanemar eru líklegri en aðrir til að upplifa kvíða og streitu (Trenz o.fl., 2015). Færri pátttakendur nefna að skyldur vegna fjölskyldu hafi neikvæð áhrif á námið en pó telja tæp 40\% svo vera. Rannsókn Jóhönnu Einarsdóttur og Sifjar Einarsdóttur (2004) leiddi skýrt í ljós hvað konurnar sem voru í leikskólakennaranámi á fyrstu árunum eftir að námið fluttist á háskólastig áttu erfitt með að samræma námið og skyldur við fjölskyldu og sú virðist enn vera raunin.

Leikskólakennaranemarnir sem tóku pátt í rannsókninni verja of litlum tíma í námið og er petta í samræmi við niðurstöður úr könnun meðal evrópskra stúdenta en par kom fram að mikil vinna með námi kom niður á peim tíma sem stúdentar notuðu í nám (Masevičiūtè o.fl., 2018). Meirihluti pátttakenda í rannsókninni var skráður í fullt nám á fyrsta námsári en reyndin var sú að innan við helmingur lauk fullu námi. Mjög lítil krafa er gerð um viðveru fjarnema í Háskóla Íslands en skyldumæting er í staðlotur sem eru tvær vikur á hvoru misseri. Í priggja ára B.Ed.-námi er pví skylduviðvera í 12 vikur en á fyrstu árum fjarnáms í Fósturskóla Íslands var viðvera fjarnema 30 vikur (Puríður Kristjánsdóttir, 1995). Fjarnemum gengur yfirleitt vel að samræma starf og mætingu í staðlotur (Amalía Björnsdóttir o.fl., 2019b) en líklega er erfiðara að finna tíma samhliða öðrum 
skyldum til að sinna náminu pegar staðlotum sleppir. Höfundar telja að petta kalli á að háskólinn og vinnuveitendur taki mið af aðstæðum óhefðbundinna stúdenta, sem í pessu tilviki eru konur sem purfa að sjá um heimili og sinna fjölskyldu jafnframt pví að sinna námi. Pær rannsóknarniðurstöður sem hér eru kynntar eru mjög samhljóma 16 ára gömlum niðurstöðum Jóhönnu Einarsdóttur og SifjarEinarsdóttur (2004). Í Noregi er sérstök námsleið fyrir fólk sem starfar í leikskólum, hún er skipulögð í samvinnu við rekstraraðila leikskóla og slíkt fyrirkomulag gæti hentað vel hér á landi. Haustið 2020 var farið af stað með nýtt fyrirkomulag í bakkalárnámi við Háskóla Íslands, svokallaða háskólamorgna. Kennsla fer pá fram fyrir hádegi einn til prjá daga í viku og stúdentar fá svigrúm til að sinna náminu á vinnutíma. Markmiðið er „að efla gæði námsins og skapa öflugt lærdómssamfélag og stuðla að pví að leikskólakennaranemum sem starfa í leikskólum verði gert kleift að sinna náminu á dagvinnutíma" (Kolbrún Pálsdóttir og Kristín Jónsdóttir, 2020). Með próun tækni til fjarkennslu er unnt að bjóða kennslu í rauntíma pannig að nemar hafi tækifæri til að taka pátt í kennslustundum frá sínum vinnustað. Unnið er að pví að koma á samstarfi við sveitarfélög um leikskólakennaranámið til að stuðla að pví að stúdentar fái svigrúm til að sinna námi samhliða starfi sínu í leikskólum og vonandi verður pað til að fleiri nái að ljúka námi.

\section{Lokaorð}

Niðurstöður rannsóknarinnar leiða í ljós að aðstæður leikskólakennaranema eru með peim hætti að lítill tími gefst til að sinna náminu og er pað líkleg skýring á hversu fáir ljúka pví. Almennt hafa fjölmargar rannsóknir, bæði íslenskar og erlendar, vakið athygli á að óhefðbundnir stúdentar purfi annars konar móttökur og stuðning í námi en hefðbundnir yngri stúdentar. Til að freista pess að brautskrá fleiri af peim sem sýna áhuga með pví að skrá sig í leikskólakennaranám parf að leita leiða til að koma á einhvern hátt til móts við aðstæður stúdentahópsins við skipulag og framkvæmd námsins og vonandi eru háskólamorgnar fyrsta skrefið í pá átt. Par er í raun verið að próa aðferðir við fjarnám með pví að nýta betur tæknina til að koma til móts við parfir peirra stúdenta sem ekki geta sótt staðnám vegna pess að aðstæður peirra eru pannig að peir purfa að vinna. Ný lög frá 2019 opna möguleika á að ljúka meistaraprófi án lokaverkefnis og líklegt er að pað auðveldi fleiri leikskólakennaranemum að ljúka námi.

Fyrirkomulag menntunar leikskólakennaranema gæti líka purft í meira mæli að taka mið af pví að meirihluti hópsins er starfandi í leikskólum og sumir með margra ára starfsreynslu við upphaf náms. Samstarf háskólanna og peirra sem reka leikskólana er mikilvægt en gera parf ráð fyrir að pað geti orðið hagsmunaárekstrar pegar leikskólakennaranemarnir hafa jafnframt hlutverk og skyldur sem starfsmenn í leikskólunum. Starfsreynslan sem leikskólakennaranemar hafa í farteskinu er mikilvæg og parf að íhuga hvort ekki megi meta hana með svokölluðu raunfærnimati sem gæti orðið til pess að stytta mætti háskólanámið eða haga pví með öðrum hætti með hliðsjón af reynslu nema.

Siłan farið var að krefjast fimm ára háskólanáms til starfsréttinda leikskólakennara hafa alltof fáir leikskólakennarar lokið námi. Krafan um meistaranám er metnaðarfull en á Norðurlöndunum er ýmist priggja eða priggja og hálfs árs bakkalárnám viðmiðið. Eftir lengingu námsins tekst ekki að mennta nægilega marga leikskólakennara til að viðhalda fjölda í stéttinni og sífellt verður lengra í land með að ákvæði um að tveir priðju starfsmanna skuli vera leikskólakennarar verði uppfyllt. Í nýrri skýrslu OECD (2020) um starfsfólk leikskóla í nokkrum löndum er vakin athygli á lágu menntunarstigi starfsfólks í íslenskum leikskólum. Mikil starfsmannavelta meðal ófaglærðra eykur enn á vandann og mikilvægt er að búa til öflugri hóp annarra starfsmanna sem líta á leikskólann sem sinn framtíðarstarfsvettvang. Petta mætti gera með styttra námi á framhalds- eða háskólastigi og væri mikilvæg viðbót við pað brýna verkefni að fjölga leikskólakennurum.

Veikleiki pessarar rannsóknar er fyrst og fremst fámenni í hópi stúdenta í leikskólakennaranámi, sem jafnframt er ástæða pess að ráðist var í hana. Pessir fáu pátttakendur gefa samt sem áður mynd af stöðu stúdentahópsins og tölur frá Hagstofu Íslands draga upp nokkuð skýra mynd af peirri próun sem átt hefur sér stað í leikskólum á síðustu tveimur áratugum hvað varðar samsetningu bæði starfsmannahópsins og nemendahópsins. 


\section{Recruitment of preschool teachers, numbers of graduates and background of preschool student teachers}

During the past two decades, the demographics of preschool children in Iceland have changed, and their school days have lengthened. The number of children aged two and younger as well as the number of children with non-Icelandic mother tongues or with special needs has increased significantly. These changes have required increased staff in preschools.

This research aims to (1) assess the current and future (over the next decade) need for preschool teachers in Iceland, based on information from Statistics Iceland and (2) seek explanations for preschool student teachers' slow academic progress and low graduation rates at the University of Iceland.

This study begins by providing contextual information on the historical development of preschool teacher education in Iceland, and the current situation in Iceland is compared to legislation on preschool teacher education in Europe, with a special focus on the Nordic countries. From 1998 to 2018, only 28\% of preschool staff working with children in Iceland were licensed preschool teachers; by law, two-thirds of staff must be licensed.

Attention is also drawn to the lack of recruitment of young preschool teachers. Agecomposition statistics show that the proportion of older teachers has increased in the past 20 years; the number of teachers aged 60 years and over has increased from 1.5\% of preschool teachers in 1998 to $17 \%$ in 2018 . This is a cause for concern, given that the number of preschool education graduates has decreased significantly since the enactment of a law that requires teachers to have graduated with a five-year master's degree instead of a three-year bachelor's degree in preschool teacher education. Another concern is that preschool student teachers progress slowly in their studies, and graduation rates are quite low in the undergraduate and graduate programmes. Too few of those who graduate from the B.Ed. programme in preschool teacher education enter the master's programme. The majority of students who graduate with the required M.Ed. enter the programme with a bachelor's degree in another subject.

To seek explanations for students' slow academic progress and low graduation rates, questionnaires were administered to preschool student teachers in their first year of study at the University of Iceland in the autumn of 2018 and 2019 and in their second year of study in 2019. Most respondents were women, and more than half were over the age of twenty-five; the majority were living with a partner and had children in their care. Most participants were 'non-traditional' university students with responsibilities outside their studies. Around $80 \%$ were in the distance education programme and worked in preschools during their studies, and $83 \%$ had worked for two years or more in a preschool before entering the programme. About half the participants worked full time or close to full time during their studies, and about two-thirds spent 20 hours or fewer per week on their studies. By the second year of their studies, $40 \%$ of the participants had completed the equivalent of one year of full-time study. Slow academic progress at the beginning of their studies indicates that students need more time than expected to complete their degree. The student teachers' backgrounds and situations demonstrated that they lack enough time to dedicate to their studies. Therefore, strategies are needed to accommodate the preschool student teachers' circumstances in the organisation and implementation of the pre-school teacher education programme. Development of technology for distance learning makes it is possible to offer teaching in real time so that students have the opportunity to participate in lessons from their workplace. 
Negotiation between universities and those who run preschools is important. There might be conflicts of interest when preschool student teachers have roles and obligations as staff members in preschools. Recent efforts have aimed at establishing co-operation with municipalities to encourage students to pursue their studies in parallel with their work in pre-schools, which will hopefully lead to more people completing their degrees.

Keywords: Preschool student teachers, preschool teacher education, non-traditional university students, distance learning, preschool teachers

\section{Um höfundana}

Amalía Björnsdóttir (amaliabj@hi.is) er prófessor við deild heilsueflingar, íprótta- og tómstunda á Menntavísindasviði Háskóla Íslands. Hún lauk B.A.-prófi í sálfræði frá Háskóla Íslands árið 1991, M.Sc.-prófi frá University of Oklahoma 1994 og doktorsprófi frá sama skóla 1996. Hún hefur lagt stund á rannsóknir á sviði mælinga og prófagerðar, lestrar- og málproskamælinga, skólastjórnunar og áhrifa félagslegra pátta á skólastarf.

Puríður Jóna Jóhannsdóttir (thuridur@hi.is) er prófessor í menntunarfræðum við deild faggreinakennslu á Menntavísindasviði Háskóla Íslands og námsbrautarformaður í menntun framhaldsskólakennara. Hún lauk B.A.-prófi í íslensku og pjóðfélagsfræði frá HÍ árið 1978, M.Ed.-prófi í menntunarfræði frá Kennaraháskóla Îslands $2001 \mathrm{og}$ doktorsprófi í uppeldis- og menntunarfræði frá HÍ 2010. Rannsóknir hennar hafa snúist um fjarnám í kennaranámi og á framhaldsskólastigi, notkun upplýsingatækni í námi og kennslu á öllum skólastigum, próun kennsluhátta í háskóla og framhaldsskóla og námskrárpróun.

\section{About the authors}

Amalía Björnsdóttir (amaliabj@hi.is) is a professor at the Faculty of Health Promotion, Sport and Leisure Studies at the School of Education, University of Iceland. She completed a B.A. degree in psychology from the University of Iceland in 1991, and a Ph.D. from the University of Oklahoma in 1996. Her major research interests are in the areas of measurement and testing (reading and language development), school management and influences of social factors in education.

Thurídur Jóna Jóhannsdóttir (thuridur@hi.is) is a professor in educational studies at the School of Education, University of Iceland and programme coordinator in pedagogy for upper secondary teachers. She completed her B.A. degree in Icelandic and sociology in 1978 at the University of Iceland, an M.Ed. degree in pedagogy in 2001 at the Iceland University of Education, and a Ph.D. in educational studies in 2010 at the University of Iceland. Her research areas include online learning, teacher education, ICT in education, development of teaching and learning in higher education and upper secondary education, and curriculum development. 


\section{Heimildaskrá}

Alila, K. (2015). Provision of quality early childcare services (Czech Republic, 10-11 November 2015): Early childhood education and care in Finland - current situation and recent trends. Sótt af https://ec.europa.eu/ social/BlobServlet?docId=14819\&langId=en

Amalía Björnsdóttir og Puríður Jóna Jóhannsdóttir. (2020). Nemendur i Menntunarfraði leikskóla að loknu BA/BS/B.Ed.-prófi haustið 2019: Spurningakönnun meðal nema i M.Ed.-námi skólaárið 2019-2020. Sótt af https://hdl.handle.net/20.500.11815/1835

Amalía Björnsdóttir, Puríður Jóhannsdóttir og Halla Jónsdóttir. (2019a). Nemar i grunnskólakennaranámi: Spurningakönnun meðal grunnskólakennaranema á fyrsta ári i B.Ed.-námi skólaárið 2018-2019. Sótt af http://www. menntavisindastofnun.hi.is/sites/menntavisindastofnun.hi.is/files/grunnskolakennaranemar_2018-2019.pdf

Amalía Björnsdóttir, Puríður Jóhannsdóttir og Halla Jónsdóttir. (2019b). Nemar i leikskólakennaranámi: Spurningakönnun meðal leikskólakennaranema á fyrsta ári i B.Ed-námi skólaárið 2018-2019. Sótt af http://www. menntavisindastofnun.hi.is/sites/menntavisindastofnun.hi.is/files/leikskolakennaranemar2018-2019.pdf

Anna Lilja Pórisdóttir. (2015, 12. maí). Fá styrk í leikskólakennaranám. Mbl.is. Sótt af https://www.mbl.is/ greinasafn/grein/1553138/

Auður Kristinsdóttir, Ásrún Matthíasdóttir og M. Allyson Macdonald. (2001). Úttekt á fjarkennslu við Kennaraháskóla Íslands. Reykjavík: Rannsóknarstofnun Kennaraháskóla Íslands.

Chesters, J. og Watson, L. (2016). Staying power: The effect of pathway into university on student achievement and attrition. Australian Journal of Adult Learning, 56(2), 225-249.

Crozier, G., Reay, D., Clayton, J., Colliander, L. og Grinstead, J. (2008). Different strokes for different folks: Diverse students in diverse institutions - experiences of higher education. Research Papers in Education, 23(2), 167-177. doi:10.1080/02671520802048703

Delaney, L. (2015). Who graduates from Irish distance university education? European Journal of Open, Distance and E-learning, 18(1), 99-113. doi: 10.1515/eurodl-2015-0007

Delaney, L. og Brown, M. (2018). To walk invisible: Distance students in a dual-mode university. Distance Education, 39(2), 209-223. doi:10.1080/01587919.2018.1457948

Delaney, L. og Farren, M. (2016). No 'self' left behind? Part-time distance learning university graduates: social class, graduate identity and employability. Open Learning: The Journal of Open, Distance and E-Learning, 31(3), 194-208. doi.org/10.1080/02680513.2016.1208553

European Commission/EACEA/Eurydice. (2019). Key data on early childhood education and care in Europe: 2019 edition. Eurydice report. Luxembourg, Brussels: Publications Office of the European Union.

Eurydice. (e.d.). National education systems. Finland. Teachers and education staff. Sótt af https://eacea.ec.europa. eu/national-policies/eurydice/content/teachers-and-education-staff-24_en

Félag leikskólakennara. (2017). Arsskýrsla 2017. Sótt af https:/www.ki.is/media/fhiluqau/fl_adalfundur2018_arsskyrsla_2017_uppfaert_110518.pdf

Field, A. (2018). Discovering statistics using IBM SPSS statistics (5. útgáfa). London: Sage.

Gils Guðmundsson. (1949). 25 ára Barnavinafélagið Sumargjöf. Reykjavík: Barnavinafélagið Sumargjöf.

Guðrún Geirsdóttir, Harpa Pálmadóttir, Rögnvaldur Ólafsson, Sólveig Jakobsdóttir, Porvaldur Pálmason og Puríður Jóhannsdóttir. (2007). Mótun stefnu i fjarkennslumálum hins sameinaða háskóla: Lokaskýrsla verkefnishóps. Sótt af http://hdl.handle.net/1946/17225

Hagstofa Íslands. (2020a). Háskólastig. Sótt af https://hagstofa.is/talnaefni/samfelag/menntun/haskolastig/

Hagstofa Íslands. (2020b). Leikskólastig. Sótt af https://hagstofa.is/talnaefni/samfelag/menntun/leikskolastig/

Hauschildt, K., Vögtle, E. M. og Gwosć, C. (2018a). EUROSTUDENT VI - Overview and selected findings: Social and economic conditions of student life in Europe. Sótt af https://www.eurostudent.eu/download_files/ documents/EUROSTUDENT_VI_short_report.pdf

Hauschildt, K., Vögtle, E. M. og Gwosć, C. (2018b). Social and economic conditions of student life in Europe: EUROSTUDENT VI 2016-2018: Synopsis of indicators. Sótt af https://www.eurostudent.eu/download_files/ documents/EUROSTUDENT_VI_Synopsis_of_Indicators.pdf 
Háskóli Íslands. (2017). Framtíðarstarfið hlaut Orðsporið 2017. Sótt af https://www.hi.is/frettir/framtidarstarfid_hlaut_ordsporid_2017

Háskóli Íslands. (2020). HÍ í tölum. Nemendur. Sótt af https://www.hi.is/kynningarefni/nemendur

Jóhanna Einarsdóttir. (2017). Öruggt og fölbreytt framtíðarstarf. Sótt af https://framtidarstarfid.is/blogg/

Jóhanna Einarsdóttir og Sif Einarsdóttir. (2004). „Á ég að vera með pvílíkum kerlingum í bekk?“ Reynsla eldri og yngri nemenda í leikskólakennaranámi. Uppeldi og menntun, 13(1), 45-66.

Jón Torfi Jónasson. (2006). Frá gaslu til skóla. Um próun leikskóla á Íslandi. Reykjavík: Félagsvísindastofnun Háskóla Íslands.

Kennaraháskóli Íslands. (2003, 2004, 2005, 2006, 2007, 2008). Arsskýrslur. Reykjavík: Höfundur.

Kolbrún Pálsdóttir og Kristín Jónsdóttir. (2020). Til leikskólakennaranema i grunnnámi haustið 2020: Kennslufyrirkomulag - Háskólamorgnar. Sótt af https://ugla.hi.is/pub/ufiles/2f/2f53035b6e/Til\%20uppl\%C3\%BDsingar\%20-\%20H\%C3\%A1sk\%C3\%B3lamorgnar\%202020-2021.pdf

Lee, K. (2017). Rethinking the accessibility of online higher education: A historical review. The Internet and Higher Education, 33(4), 15-23. doi:10.1016/j.iheduc.2017.01.001

Levin, J. S. (2007). Nontraditional students and community colleges: The conflict of justice and neoliberalism. New York: Palgrave MacMillan.

Lög um fósturskóla Íslands nr. 10/1973.

Lög um leikskóla nr. 48/1991.

Lög um leikskóla nr. 78/1994.

Lög um menntun og ráðningu kennara og skólastjórnenda við leikskóla, grunnskóla og framhaldsskóla nr. $87 / 2008$.

Lög um menntun, hæfni og ráðningu kennara og skólastjórnenda við leikskóla, grunnskóla og framhaldsskóla nr. 95/2019.

Malm, B. (2017). "We need to give the profession something that no one else can": Swedish student teachers' perceptions and experiences of their preschool teacher training programme. International Journal of Learning, Teaching and Educational Research, 16(9), 73-87. doi:10.26803/ijlter.16.9.6

Marginson, S. (2016). The worldwide trend to high participation higher education: Dynamics of social stratification in inclusive systems. Higher education, 72(4), 413-434. doi.org/10.1007/s10734-016-0016-x

Masevičiūtè, K., Šaukeckienè, V. og Ozolinčiūtė, E. (2018). EUROSTUDENT VI Thematic report-combining studies and paid jobs. Sótt af https://www.eurostudent.eu/download_files/documents/TR_paid_jobs.pdf

Menntamálaráðuneytið. (1985). Uppeldisáatlun fyrir dagvistarheimili. Reykjavík: Höfundur.

Menntamálaráduneytið. (1993). Uppeldisáatlun fyrir leikskóla : markmið og leiðir. Reykjavík: Höfundur.

Menntamálaráduneytið. (1999). Aðalnámskrá leikskóla. Reykjavík: Höfundur.

Mishra, S. (2020). Social networks, social capital, social support and academic success in higher education: A systematic review with a special focus on 'underrepresented' students. Educational Research Review, 29, 100307. doi:10.1016/j.edurev.2019.100307

OECD. (2020). Building a high-quality early childhood education and care workforce: Further results from the starting strong survey 2018, TALIS. doi:10.1787/b90bba3d-en

Ríkisendurskoðun. (2017). Kostnaður og skilvirkni kennaramenntunar. Háskóli Íslands og Háskólinn á Akureyri. Sótt af https://rikisendurskodun.is/wp-content/uploads/2017/02/SU-kostnadur_og_skilvirkni_kennaramenntunar_HI_og_HA.pdf

Sif Einarsdóttir og Jóhanna Einarsdóttir. (2002). Fátt er reynslunni fróđara: Námsgengi ólíkra nemendahópa í leikskólakennaranámi. Uppeldi og menntun, 11(1), 81-99.

Statistics Denmark. (e.d.). Fulltimeadjusted staff in municipal and self-governing institutions. Sótt af https://m. statbank.dk/TableInfo/BOERN1

Statistics Norway (e.d). Employees in kindergartens, by competence and occupation. Sótt af https://www.ssb. no/en/utdanning/statistikker/utdansatte/aar 
Stjórnarráðið. (2017). Framtíðarstarfið hlaut Orðsporið 2017. Sótt af https://www.stjornarradid.is/efst-a-baugi/ frettir/stok-frett/2017/02/06/Framtidarstarfidhlaut-Ordsporid-2017/

Trenz, R. C., Ecklund-Flores, L. og Rapoza, K. (2015). A comparison of mental health and alcohol use between traditional and nontraditional students. Journal of American College Health, 63(8), 584-588. doi.org/10.1 080/07448481.2015.1040409

Utdanning.no. (e.d.). En nasjonal nettportal for informasjon om utdanning og yrke, med oversikt over det norske utdanningstilbudet. Sótt af https://utdanning.no/studiebeskrivelse/barnehagelaererutdanning

Valborg Sigurðardóttir. (1998). Fósturskóli Íslands. Afmalisrit i tilefni af 50 ára afmali skólans. Reykjavík: Gott mál.

Puríður Jóna Jóhannsdóttir og Amalía Björnsdóttir. (2018). Staðnemar og farnemar í grunnskólakennaranámi við Menntavísindasvið: Bakgrunnur, viðhorf og áhugi á að starfa við kennslu. Netla - Veftimarit um uppeldi og menntun. doi:10.24270/netla.2018.11

Puríður Jóhannsdóttir og Amalía Björnsdóttir. (2020). Online teacher education: A way to create a more diverse teacher workforce. Í M. Brown, M. N. G. Mhichil, E. Beirne og E. Costello (ritstjórar), Proceedings of the 2019 ICDE world conference on online learning (1. bindi, bls. 476־484). Dublin: Dublin City University. doi:10.5281/zenodo.3804014

Puríður Kristjánsdóttir. (1995). Fjarnám. Fósturskóli Íslands. Reykjavík: Höfundur.

Amalía Björnsdóttir og Puríður Jóna Jóhannsdóttir. (2020).

Nýliðun leikskólakennara, fjöldi brautskráðra og bakgrunnur leikskólakennaranema.

Netla - Veftímarit um uppeldi og menntun. Menntavísindasvið Háskóla Íslands.

Sótt af http://netla.hi.is/greinar/2020/ryn/12

DOI: https://doi.org/10.24270/netla.2020.12 